\title{
Composite scaffolds for cartilage tissue engineering based on natural polymers of bacterial origin; thermoplastic Poly(3- hydroxybutyrate) and micro-fibrillated bacterial cellulose
}

\author{
Akaraonye Everest ${ }^{1}$, Filip Jan ${ }^{2}$, Safarik Mirka ${ }^{3}$, Salih Vehid ${ }^{6}$, Keshavarz \\ Tajalli ${ }^{1}$, Knowles Jonathan ${ }^{4,5}$ and Roy Ipsita ${ }^{1}$ *
}

${ }^{1}$ Applied Biotechnology Research Group, Department of Life Sciences, Faculty of Science and Technology, University of Westminster, London WIW 6UW, UK

${ }^{2}$ Centre for Nanomaterial Research, Faculty of Science, Palacky University in Olomouc,Tr. 17. Listopadu 12, 77146 Olomouc, Czech Republic

${ }^{3}$ Istitute of Systems Biology and Ecology AS CR Na Sadkach 7, 37005 Ceske Budejovice, Czech Republic

${ }^{4}$ Department of Biomaterial \& Tissue Engineering, Eastman Dental Institute, University College London, WC1X 8LD, UK

${ }^{5}$ WCU Research Centre of Nanobiomedical Science, Dankook University, San\#29, Anseodong, Dongnam-gu, Cheonan-si, Chungnam, South Korea

${ }^{6}$ Plymouth University Peninsula Schools of Medicine and Dentistry, Portland Square, Drake Circus, Plymouth, Devon, PL4 8AA

*Corresponding author

Professor Ipsita Roy

Department of Life Sciences, Faculty of Science and Technology,

University of Westminster,

115 New Cavendish Street, London W1W 6UW, UK

Phone: +44-207-995000

Fax: $+44-207-995800$ 


\begin{abstract}
Cartilage tissue engineering is an emerging therapeutic strategy that aims to regenerate damaged cartilages caused by disease, trauma, ageing or developmental disorder. Since cartilage lacks regenerative capabilities, it is essential to develop approaches that deliver the appropriate cells, biomaterials, and signalling factors to the defect site. Materials and fabrication technologies are therefore critically important for cartilage tissue engineering in designing temporary, artificial extracellular matrices (scaffolds), which support threedimensional cartilage formation. Hence, this work aimed to investigate the use of Poly(3hydroxybutyrate), $\mathrm{P}(3 \mathrm{HB}) /$ microfibrillated bacterial cellulose (MFC) composites as 3Dscaffolds for potential application in cartilage tissue engineering. The compression moulding/particulate leaching technique employed in the study resulted in good dispersion, and a strong adhesion between the MFC and $\mathrm{P}(3 \mathrm{HB})$ matrix. Furthermore, the composite scaffold produced displayed better mechanical properties than the neat $\mathrm{P}(3 \mathrm{HB})$ scaffold. Addition of 10, 20, 30, and $40 \mathrm{wt} \% \mathrm{MFC}$ to the $\mathrm{P}(3 \mathrm{HB})$ matrix, the compressive modulus was found to have increased by 35, 37, 64 and 124\%, while the compression yield strength increased by $95,97,98$ and $102 \%$ resepectively with respect to neat $\mathrm{P}(3 \mathrm{HB})$. Both cell attachment and proliferation was found to be optimal on the polymer-based 3D composite scaffolds produced, indicating a non-toxic and highly compatible surface for the adhesion and proliferation of the mouse chondrogenic ATDC5 cells. The large pores sizes $(60-83 \mu \mathrm{m})$ in the 3D scaffold allowed infiltration and migration of ATDC5 cells deep into the porous network of the scaffold material. Overall this work confirmed the potential of $\mathrm{P}(3 \mathrm{HB}) / \mathrm{MFC}$ composites as novel materials in cartilage tissue engineering.
\end{abstract}

KEYWORDS: Polyhydroxyalkanoates, Poly(3-hydroxybutyrate), Bacterial cellulose, micro fibrillated cellulose, tissue engineering scaffold, Composite materials 


\section{Introduction}

Tissue engineering is a promising therapeutic strategy that has the potential to provide solutions for the repair or regeneration of diseased or damaged tissues. Tissue engineering was officially coined in 1988 at a National Science Foundation workshop, and defined by Langer and Vacanti to mean "the application of principles and methods of engineering and life sciences towards the fundamental understanding of structure-function relationships in normal and pathological mammalian tissues and the development of biological substitute to restore, maintain or improve tissue function ${ }^{1}$. The main challenge of tissue engineering is to mimic what happens in nature. Whilst, attempts are being made to engineer practically every tissue and organ in the body in vitro, work is also proceeding in creating tissue engineered organs such as liver, nerve, kidney, pancreas, heart muscle and valves, ligament, bones and cartilages. To date, the highest rates of success have been achieved in the areas of $\operatorname{skin}^{2}$, bladder ${ }^{3}$, airway ${ }^{4}$ and bone ${ }^{5,6}$ where tissueengineered constructs have been used successfully in patients. In addition, autologous chondrocyte implantation (ACI) and matrix-induced autologous chondrocyte implantation (MACI) are showing some success for cartilage repair. While major breakthroughs have taken place, significant research is required in a number of specific areas in the field ${ }^{7}$.

The basic approach to tissue engineering involves the use of cells (isolated cells or cell substitute), three dimensional scaffolds and the delivery of signal factors such as growth and differential factors to targeted locations ${ }^{8}$. These approaches can be used alone or in combination to facilitate the repair, replacement or regeneration of damaged or degenerated tissues cause by disease, injuries or trauma. The use of isolated cells or tissue-inducing substances is considered when the defects are small and well contained. To engineer tissues of practical size scale and predetermined shapes, these two approaches are seriously limited. Hence, growing cells in three-dimensional scaffolds play a pivotal role. Scaffolds, therefore, plays a key role in guiding cells to grow, synthesize extracellular matrix and other biological molecules, and facilitate the formation of functional tissues and organs ${ }^{9}$.

Generally, in designing Tissue engineering scaffolds, few basic requirements have been widely accepted $^{10}$. First, a scaffold has to have interconnected pore structures, high porosity and proper pore size to allow for cellular penetration and diffusion of nutrients and waste products ${ }^{11}$. Second, a high surface area ${ }^{12-14}$ is needed to enhance high ligand density and promote cell adhesion, cell viability, migration, differentiation and extracellular matrix production. Third, biodegradability ${ }^{15}$ is highly desirable, and a proper degradation rate is needed to match the rate of neotissue formation. Fourth, the scaffold should be biocompatible ${ }^{16-19}$ to the cells and adhere and integrate with the surrounding native bone or cartilage. Fifth, the scaffold should be able 
to provide mechanical integrity ${ }^{16-18}$ depending on the defect location. The mechanical properties of the substrate to which the cells are attached are critical to the regulation of cellular mechanotransduction and subsequent cellular behavior. This has important implications for development, differentiation, disease, and regeneration. Albeit enormous success recorded in scaffold production, lack of vascularity in tissue engineered constructs has been a major challenge, and improving vascularisation strategies is considered one of the areas requiring the most extensive research in the field of tissue engineering ${ }^{20}$. Consequently, increasing research is being directed towards utilizing the mechanosensitive capacity of cells to develop tissue engineering scaffolds with specific mechanical properties that can be used to direct the behavior of the cells with which they interact ${ }^{21}$. The outcome of these researches is the development of a range of fabrication techniques aimed at producing scaffolds with adequate properties for tissue engineering. The techniques developed include; solvent casting ${ }^{22-25}$, phase inversion $^{26,27}$, fiber bonding ${ }^{28-30}$, melt based technologies ${ }^{31-35}$, high pressure based methods ${ }^{36,37}$, freeze drying ${ }^{38,39}$, electrospinning ${ }^{40}$ and rapid prototyping technologies ${ }^{41-48}$.

There are a series of problems associated with the use of scaffolds fabricated from a single phase biomaterial using the techniques enumerated above. For example, ceramic scaffolds, such as hydroxyapatite (HA), Bioglass and tri-calcium phosphate (TCP), are widely used for bone regeneration applications. Ceramic scaffolds (though, not generally used for soft tissue engineering) are typically characterized by high Young's modulus, very low elasticity, and a hard brittle surface. From a bone perspective, they exhibit excellent biocompatibility due to their chemical and structural similarity to the mineral phase of native bone. Ceramics have been used extensively due to their osteoconductivity and osetoinductivity ${ }^{49,50}$. However, these materials have some major drawbacks owing to their brittleness which presents low mechanical stability and difficulty of shaping for implantation, thus, discouraging their use in the regeneration of large bone defects. Furthermore, due to factors that happen in vivo, such as osteoclastic activity, their degradation/dissolution rates are difficult to predict ${ }^{51}$.

Different types of synthetic polymers have been used in the attempt to produce scaffolds including polystyrene, poly-l-lactic acid (PLLA), polyglycolic acid (PGA) and poly-dl-lacticco-glycolic acid (PLGA). Whilst these materials have proved to be successful as they can be fabricated with a tailored architecture, and their degradation characteristics can be controlled by varying the polymer matrix or the composition of the individual polymer ${ }^{52-54}$, they still have some drawbacks including the risk of rejection due to reduced bioactivity. In addition, there are concerns over the degradation process of PLLA and PGA as they degrade by hydrolysis, 
producing lactic acid/glycolic acid, thereby lowering the local $\mathrm{pH}$ which can lead to cell and tissue necrosis ${ }^{55}$.

The third commonly used approach is the use of biological materials in Tissue Engineering scaffold fabrication. Biological materials including collagen, various proteoglycans, alginatebased substrates and chitosan have all been used in the production of scaffolds for tissue engineering. Unlike synthetic polymer-based scaffolds, natural polymers are biologically active and typically promote excellent cell adhesion and growth. Furthermore, they are also biodegradable and so allow host cells, over time, to produce their own extracellular matrix and replace the degraded scaffold. However, fabricating scaffolds from biological materials with homogeneity and reproducible structures presents a challenge. In addition, the scaffolds generally have poor mechanical properties, which limit their use in, for example, load bearing orthopaedic applications.

The problems described above, from the use of single phase substrates, have resulted in considerable research being devoted to the development of composite scaffolds comprising more than one phase. For example, a number of groups have attempted to introduce ceramics into polymer-based scaffolds ${ }^{56-59}$ while others have combined synthetic polymers with natural polymers $^{60}$ in order to enhance their biological activity. Whilst, the resultant composite scaffolds have shown some promises, each consists of at least one phase which is not found naturally in the body and they all have associated problems with biocompatibility, biodegradability or both. A more typical approach is the use of natural polymer-based composite scaffolds to enhance biological and/or mechanical properties.

Among the available bio-based fillers, bio-based bacterial cellulose are considered a very attractive material because of their good mechanical properties (high aspect ratio, high tensile strength, Young's Modulus), high purity, crystallinity, high degree of polymerization, abundant from renewable resources, high liquid loading capacity, biodegradability, biocompatibility (induce negligible foreign body and inflammatory responses), non-toxicity, and sustainability ${ }^{61-66}$. The biocompatibility of BC-based products have made them suitable for several biomedical applications, including membranes for wound dressings ${ }^{67}$, scaffolds for tissue engineering ${ }^{68-72}$, substrates for cell seeding ${ }^{73}$, structures for biomineralization of hydroxyapatite ${ }^{74}$. It has been proven that $\mathrm{BC}$ nanofibres can mimic collagen nanofibres for Ca$\mathrm{P}$ minerals deposition through biomineralization. The resultant $\mathrm{Ca}-\mathrm{P}$ minerals are platelet-like calcium-deficient hydroxyapatite (Hap), similar to the hydroxyapatite found in natural bone ${ }^{75}$. The objectives of this work therefore, were to investigate the use of a natural polymer-based (microfibrillated cellulose, MFC and $\mathrm{P}(3 \mathrm{HB}) 3 \mathrm{D}$ composite scaffold for articular cartilage 
repair. To our knowledge, this is the first report of the use a bio-based polymeric composite scaffold for potential use in articular cartilage repair.

Cartilage is a flexible connective tissue found in many areas of the human body, including the joints, ribs, nose, ear, trachea and intervertebral discs. In these regions cartilage can act as structural support, maintain shape or absorb shock during physical exercise. Cartilage defects resulting from aging, joint injury, and developmental disorders can cause unbearable joint pains, and in some cases result in loss of mobility. Furthermore, considering the current high aging population and the growing problem of obesity, there has been increasing number of osteoarthritis patients' cases. Besides, with a more active adult population, cartilage damage resulting from sports injuries can often result in premature cartilage degeneration, thus, necessitating the need for proactive research in the treatment and engineering of injured and damaged cartilage tissues. Unlike most other connective tissues, cartilage is predominantly avascular leading to hypoxic environments that limit the rate of cellular growth and tissue regeneration $^{76,77}$. This in turn limits the capacity of cartilage to repair itself in the event of damage. Due to its limited ability to self repair, cartilage therefore is an ideal candidate for tissue engineering.

\section{Experimental Procedures}

\subsection{Bacterial strain, cells and culture medium}

Poly(3-hydroxybutyrate) was produced following previously developed biotechnological methods. ${ }^{78}$ The bacterial cellulose was produced by A. xylinus (JCM10150), obtained from the Culture Collection of University of Westminster, London, UK and grown in YGC medium containing in $\left(\mathrm{gL}^{-1}\right)$ : Yeast extract, 5.0; calcium carbonate, 12.0; glucose, 50.0) and maintained at $30{ }^{\circ} \mathrm{C}$, pH 5.0 for 5 days.

The proliferation assays were performed using Murine ATDC5 cell line. ATDC5 is an excellent in vitro model cell line for skeletal development. The cell line was grown in chondrogenic media containing; low glucose Dulbecco's Modified Eagle Medium (DMEM), supplemented with $10 \%$ fetal calf serum, $1 \%(\mathrm{w} / \mathrm{v})$ penicillin and $1 \%(\mathrm{w} / \mathrm{v})$ streptomycin solution, $5 \mathrm{ng} \mathrm{mL} \mathrm{m}^{-1}$ transformed growth factor Beta-3 (TGF $\beta-3$ ), $50 \mu \mathrm{g} \mathrm{mL}$ ascorbate-2-phosphate, $1 \mu \mathrm{M}$ dexamethasone, $0.1 \mathrm{mM}(100 \mathrm{x})$ nonessential amino acids, and $5 \mu \mathrm{g}$ $\mathrm{mL}^{-1}$ Insulin. The media for the cell lines were changed every two days and maintained at $37^{\circ} \mathrm{C}$, $5 \% \mathrm{CO}_{2}$ and passaged on confluence by adding $2 \mathrm{~mL}$ of trypsin and incubate for 5 mins.

\subsection{Production of micro-fibrillated bacterial cellulose}


Batch cultures of Acetobacter xylinum (JCM10150) were grown in flasks at $27^{\circ} \mathrm{C}$ under static condition and were harvested after five days of incubation. The cellulose pellicles formed were harvested, boiled in a $2 \%(\mathrm{w} / \mathrm{v}) \mathrm{NaOH}$ solution and washed several times with de-ionised water to remove the sodium hydroxide. The gel-like pellicles produced were first blended with a blender (Osterizer blender, Pulse matic, UK) to break down the pellicles to smaller pieces and later homogenised using a homogenizer (Bucks Laboratory Mixer Emulsifier, UK) to produce microfibrillated bacterial cellulose (MFC).

The MFC produced were later chemically modified to produce relatively hydrophobic MFC by treating water excluded MFC with a solution containing a mixture of acetic acid, toluene and perchloric acid in a ratio of (200:250:1) $\mathrm{mL}$, respectively in a stoppered flat bottom flask. The suspension of MFC in the mixture above was homogenised for 2 min before the addition of desired amount of acetic anhydride and stirred at room temperature for $72 \mathrm{~h}$. At the end of the reaction, the suspension was centrifuged at $4600 \mathrm{rpm}(12,000 \mathrm{~g})$ for $30 \mathrm{~min}$ and subsequently washed three times with a toluene/ethanol/acetone mixture ( $4: 1: 1$ by volume) to remove unreacted compounds and by-products formed during the acetylation reaction.

\subsection{Composite scaffold production}

$\mathrm{P}(3 \mathrm{HB})$ and $\mathrm{P}(3 \mathrm{HB}) / \mathrm{MFC}$ composite Scaffolds were prepared using the novel compression moulding/particulate leaching technique developed and by employing sucrose grains as the porogen for porosity. The porogen was prepared by placing small quantity of sucrose grains atop a mesh with $100 \mu \mathrm{m}$ openings. The mesh was shaken to allow sucrose grains with sizes smaller than $100 \mu \mathrm{m}$ to pass through the mesh. The process was repeated with $80 \mu \mathrm{m}$ opening mesh, however, with the sucrose that passed through the $100 \mu \mathrm{m}$ openings. The sucrose grains retained by the $80 \mu \mathrm{m}$ opening mesh $(80-100 \mu \mathrm{m}$ in size) were later collected and used for the study. The mould for the scaffold fabrication was prepared by cutting open the other end of a $5 \mathrm{~mL}$ disposable syringe to form a cylinder.

For $\mathrm{P}(3 \mathrm{HB})$ scaffold preparation, $1.0 \mathrm{~g}$ of $\mathrm{P}(3 \mathrm{HB})$ was dissolved in $10 \mathrm{~mL}$ of chloroform and $20 \mathrm{~g}$ of sucrose grains, prepared above, was added. The resulting mixture was stirred to obtain a homogenous paste. The semi-solid paste formed was placed into a prepared cylinder above. With the help of a plunge, the semi-solid paste was moulded into shape by applying pressure up to 10 bars in the cylinder. The moulded cylindrical solids were air dried at $30^{\circ} \mathrm{C}$. 
For $\mathrm{P}(3 \mathrm{HB}) / \mathrm{MFC}$ scaffold preparation $1.0 \mathrm{~g}$ of $\mathrm{P}(3 \mathrm{HB})$ was dissolved in $10 \mathrm{~mL}$ of chloroform and appropriate amounts of modified MFC were separately dissolved in chloroform and homogenised. Each of the appropriate amounts of homogenised MFC was later mixed with $\mathrm{P}(3 \mathrm{HB})$ solution and sonicated for 1 min (Ultrasonic Homogenizers US200, Philip Harris Scientific, UK) to improve the dispersion of the modified MFC in the $\mathrm{P}(3 \mathrm{HB})$ solution. $20 \mathrm{~g}$ of sucrose grains (prepared above) was later added to the $\mathrm{P}(3 \mathrm{HB})$ solution and stirred to form a semi-solid paste. The semi-solid paste formed was later moulded into shape as described above. The moulded cylindrical solids were air dried at $30^{\circ} \mathrm{C}$ for $6 \mathrm{~h}$ and later immersed in $500 \mathrm{~mL}$ of deionised water (which was occasionally changed) for $12 \mathrm{~h}$ to allow complete dissolution of sugar grains from the solid cylindrical body. After about $12 \mathrm{~h}$ the porous scaffolds were removed from the water and air dried at $30^{\circ} \mathrm{C}$. The porous scaffolds were sectioned using sharp blades to cut scaffolds in the size of $0.5 \times 0.5 \times 0.5 \mathrm{~cm}^{3}$ for further experiments including characterisation and bioactivity.

\subsection{Scaffold characterisation}

Scanning electron microscopy (SEM): Scanning electron microscopy (SEM) was used to examine the microstructure of the 3D scaffolds samples. Samples were sectioned using a sharp blade and placed on a freshly cleaved $8 \mathrm{~mm}$ diameter aluminium stubs and gold plated for $2 \mathrm{~min}$. Images were taken at various magnifications and acceleration voltages (max. of $20 \mathrm{kV}$ ) to avoid beam damage to the polymer. For each image at least 20 pore throats were measured, taking the longer diameter in the cases where the throat appeared elliptical because of perspective.

Mechanical test: The compressive strength of $\mathrm{P}(3 \mathrm{HB})$ and $\mathrm{P}(3 \mathrm{HB}) / \mathrm{MFC}$ composite scaffolds was measured using a Perkin-Elmer Dynamic Mechanical Analyser (DMA 7e, Perkin-Elmer Instruments, USA) at room temperature as described elsewhere. ${ }^{79}$ Cylindrical samples of $2 \mathrm{~mm}$ diameter and around $2 \mathrm{~mm}$ height were cut with surgical scalpels, and then compressed. The initial load was set at $1 \mathrm{mN}$ and it was increased to $6000 \mathrm{mN}$ at a rate of $200 \mathrm{mN} \mathrm{min}{ }^{-1}$. Four repeat specimens were tested for each sample during this analysis and the results presented in this work are average of four measurements. Elastic modulus of the scaffold was determined using a stress strain representation. Methodology for curve interpretation and modulus calculation was taken from ASTM D1621-04a standard 'Compressive properties of rigid cellular plastics'. 
Porosity measurements on the scaffolds: The gravimetric method was employed in measuring the porosity of the fabricated scaffolds. The samples were weighed dry, and then filled with distilled water under vacuum, and subsequently weighed again. Porosity was calculated as the quotient of the volume of pores (see below) and the total volume of the scaffold.

The volume of pores, $\mathrm{V}_{\text {pore, }}$ was deduced from the weight difference between dry $\left(m_{d r y}\right)$ and wet $\left(m_{w e t}\right)$ sample, according to equation below assuming that the amount of water absorbed by the scaffold composite phase is negligible due to its high hydrophobicity. ${ }^{80}$ Thus, the volume of pores equals the volume occupied by the absorbed water.

$$
V_{\text {pore }}=\frac{m_{\text {wet }}-m_{\text {dry }}}{d_{\text {water }}}
$$

, where, $d_{\text {water }}$ is the density of water.

The volume of $\mathrm{P}(3 \mathrm{HB})$ and $\mathrm{P}(3 \mathrm{HB}) / \mathrm{MFC}$ was calculated from the dry weight of the scaffold assuming a density of $\mathrm{P}(3 \mathrm{HB})$ about $1.25 \mathrm{gcm}^{-3}$, which corresponds to the average crystallinity measured by DSC. Density was calculated on the basis of amorphous phase and crystalline phase densities of 1.18 and $1.26 \mathrm{gcm}^{-3}$, respectively. ${ }^{81}$ For each sample type, at least five measurements were carried out and the obtained values were averaged.

\subsection{Protein Adsorption}

The protein adsorbed by the neat $\mathrm{P}(3 \mathrm{HB})$ and $\mathrm{P}(3 \mathrm{HB}) / \mathrm{MFC}$ composite samples was quantified by a Micro-BCA assay using the supplier instructions (Perce, USA). The protein adsorbed on each of the samples was extracted by an immersion in $500 \mu 1$ of $10 \%$ SDS and incubated for $24 \mathrm{~h}$ at room temperature.

After $24 \mathrm{~h}$, the protein adsorption capacity of the neat $\mathrm{P}(3 \mathrm{HB})$ and composite scaffold samples were evaluated. Materials were incubated with complete culture medium for $30 \mathrm{~min}$. After the immersion, proteins were desorbed with a $10 \%$ SDS solution and loaded on $10 \%$ SDS-page electrophoresis gels. Gels were scanned with a denitometric 'OneDscan apparatus' (Scan Metrix, France). Protein concentration was obtained by comparison with BSA standards.

\subsection{Change in $\mathrm{pH}$ of the immersed $S B F$ of the neat $P(3 H B)$ and $P(3 H B) / M F C 3 D$ composite}

For in vitro change in $\mathrm{pH}$ assessment, a total of nine samples from each group were immersed in SBF for 1, 2, 3 and 4 weeks and $20 \mathrm{~mL}$ PBS was used for each sample. The pH-values of 
SBF were monitored every week by an electrolyte-type $\mathrm{pH}$ meter (PHS-2C, Jingke Leici Co., Shanghai, China). Three samples from each group were removed from the SBF at the predetermined time point (1, 2, 3 and 4 weeks) and the $\mathrm{pH}$ of the SBF was measured with the $\mathrm{pH}$ probe. The average values for the $\mathrm{pH}$ readings were recorded.

\subsection{In vitro proliferation assays}

A cell seeding density of 100000 cells $\mathrm{cm}^{-2}$ was used for the scaffolds. The samples were placed in a polystyrene 24 well flat bottomed tissue culture plate (TPP, Switzerland), with the scaffold samples placed in the centre of the well and $30 \mu \mathrm{L}$ of the cell suspended media was added for attachment of the ATDC5 cells. The plates were incubated in a humidified environment $\left(37^{\circ} \mathrm{C}, 5 \% \mathrm{CO}_{2}\right)$ for $3 \mathrm{~h}$ to enable the cells to attach to the test material. After $3 \mathrm{~h}, 1 \mathrm{~mL}$ of chondrogenic media was added to each of the wells containing cell seeded scaffolds and the plates were replaced in the humidified incubator and maintained at $37^{\circ} \mathrm{C}, 5 \% \mathrm{CO}_{2}$. Neat $\mathrm{P}(3 \mathrm{HB})$ scaffold was used as the control. The media in the wells were changed every 2 days. The cellular growth at 24, 96 and $168 \mathrm{~h}$ (1, 4 and 7 days) of incubation was evaluated by Alamar Blue assay (AbD Serotec, UK). Alamar Blue was added to the samples (10\% v/v of the medium) and incubated at $37^{\circ} \mathrm{C}$ in an incubator (with $5 \% \mathrm{CO}_{2}$ ) for $4 \mathrm{~h}$. Aliquots of $200 \mu \mathrm{L}$ from each sample well were transferred to a black 96-well plate and the fluorescence of Alamar blue was measured using a fluorescence plate reader (Fuoroskan, Lab Systems) at an excitation wavelength of $530 \mathrm{~nm}\left(\mathrm{~A}_{530}\right)$ and an emission wavelength of $590 \mathrm{~nm}\left(\mathrm{~A}_{590}\right)$. The experiment was performed in triplicates while readings were taken in duplicates.

\subsection{Total protein production analysis}

For the measurement of total protein produced by the mouse chondrogenic ATDC5 cell lines, osteogenic media was prepared by addition of dexamethasone solution to a final concentration of $0.1 \mu \mathrm{M}$ and Ascorbic acid 2-phosphate solution to a final concentration of $0.2 \mathrm{mM}$ to a low glucose Dulbecco's Modified Eagle Medium (DMEM), supplemented with 10\% fetal calf serum, $1 \%(\mathrm{w} / \mathrm{v})$ penicillin and $1 \%(\mathrm{w} / \mathrm{v})$ streptomycin solution. The ATDC5 cells were seeded to the scaffolds and grown using freshly prepared osteogenic medium. Aliquots of supernatants were taken at day 1, 7, 14 and 21 days for the quantification of total protein produced by the cells using Qubit ${ }^{\mathrm{TM}}$ Protein Assay Kits and by following the protocols in the manufacturers' manual.

The Qubit ${ }^{\circledR} 2.0$ Fluorometer gives values for the Qubit ${ }^{\mathrm{TM}}$ protein assay in $\mu \mathrm{g} / \mathrm{mL}$. This value corresponds to the concentration after sample was diluted into the assay tube. To calculate the concentration of sample, the following equation was used: 
Concentration of sample $=\mathrm{QF}$ value $\times \frac{200}{\mathrm{X}}$

Where, $\mathrm{QF}$ value $=$ the value given by the $\mathrm{Qubit}^{\circledR} 2.0$ Fluorometer, $\mathrm{X}=$ the number of microliters of sample added to the assay tube.

\subsection{Results}

$\mathrm{P}(3 \mathrm{HB})$, produced from Bacillus cereus SPV and chemically modified MFC were combined to form $\mathrm{P}(3 \mathrm{HB}) / \mathrm{MFC}$ composite $3 \mathrm{D}$ scaffolds, using a novel compression moulding/particulate leaching technique developed in this work. Sucrose grains of sizes 80-100 $\mu \mathrm{m}$ were used as porogen materials. The 3D composite scaffold were characterised thoroughly. Detailed results of the production and characterisation of the materials are given below.

\subsection{Preparation of $P(3 H B) / M F C$ composite scaffold}

$\mathrm{P}(3 \mathrm{HB}) / \mathrm{MFC}$ composite scaffolds were prepared using a novel compression moulding/particulate leaching technique. This novel technique was developed in this study using an inexpensive technique which can be carried out at room temperature. The dimension of the scaffolds produced using this technique is alterable as shown in Fig. 1(A) and (B). Also, the porosity of the scaffolds can be controlled by adjusting the size and amount of the porogen material (sucrose grain). The mechanical strength of the scaffold can be altered and controlled by adjusting the amount of $\mathrm{P}(3 \mathrm{HB})$ and filler employed in the composite production. Also, the shape of the pores in the scaffold can be varied and this is dependent on the shape of the porogen material employed during scaffold fabrication.
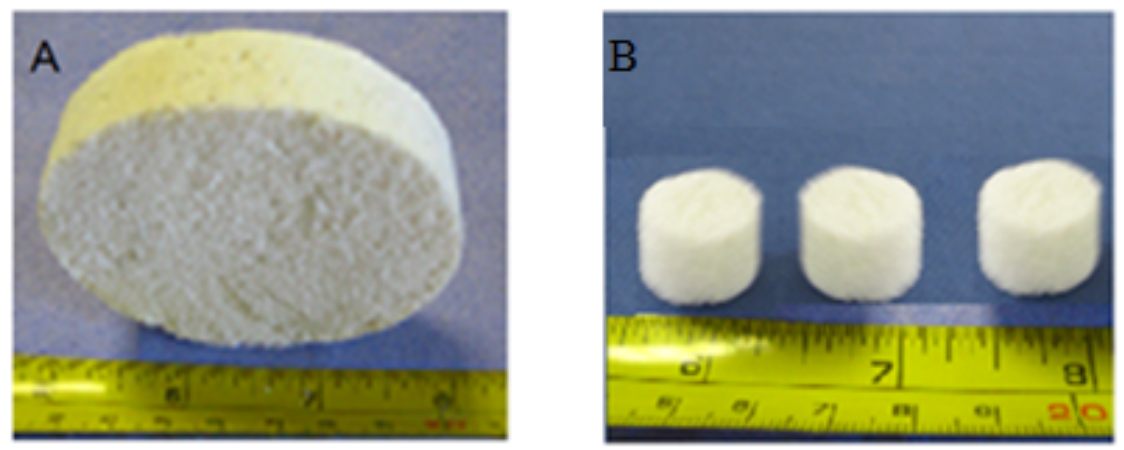
Figure 1: Digital images of different dimensions and type of scaffolds that were produced using the compression moulding/particulate leaching technique.

\subsection{Microstructural characterisation of $P(3 H B) / M F C$ Composite $3 D$ Scaffolds}

A selection of SEM micrographs of the fractured surface of composite materials with $40 \%$ of MFC produced using the novel compression moulding/particulate leaching technique is shown in Fig. 2. Two different magnifications were used in order to display both the MFC dispersion within the $\mathrm{P}(3 \mathrm{HB})$ matrix and the interfacial adhesion between the two composite components. The SEM image of the surface of the scaffold highlights the interconnected pore network in the scaffold microstructure, Fig. 2(a) and (b). This is necessary for the infiltration of cells during cartilage regeneration. Fig. 2(c) displayed the SEM image of the morphology of pores in the scaffold highlighting the microtopography of the surface of the pore throat (inside pore).
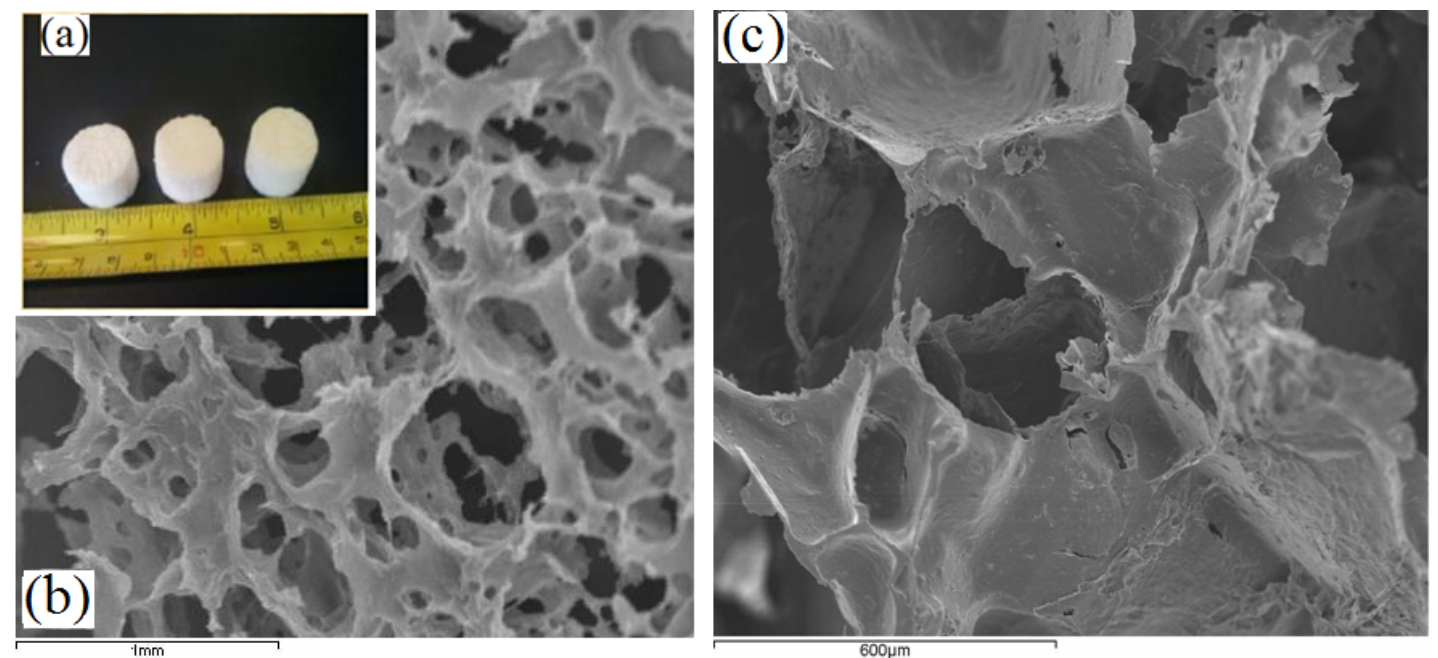

Figure 2 (a) Digital imge of the $\mathrm{P}(3 \mathrm{HB}) / \mathrm{MFC}$ scaffold after particulate leaching; (b) SEM image of $\mathrm{P}(3 \mathrm{HB}) / \mathrm{MFC}$ composite scaffold at lower magnification showing the microstructural pores in $\mathrm{P}(3 \mathrm{HB}) / \mathrm{MFC}$ scaffold; (c) SEM image of $\mathrm{P}(3 \mathrm{HB}) / \mathrm{MFC}$ composite scaffold at higher magnification displaying the irregular pore structure with high interconnectivity.

\subsection{Compression tesing:}

The effect of MFC content on the large strain behavior of $\mathrm{MFC} / \mathrm{P}(3 \mathrm{HB})$ composites was investigated up to their failure. Figure 3 shows a typical stress-strain curve of neat $\mathrm{P}(3 \mathrm{HB})$ and $\mathrm{P}(3 \mathrm{HB}) / \mathrm{MFC}$ composite of various MFC content $(10,20,30,40$, and 50 $w t \%)$ tested in air. The curves demonstrated the typical behaviour of a scaffold 
undergoing deformation and comprise three distinct regions: a linear-elastic region followed by a plateau of roughly constant stress leading into a final region of steeply rising stress. The linear-elastic region represents the period of loading of the 3D scaffold with strain. At this stage, the 3D scaffold can still withstand the strain applied to it without much deformation. As the strain increases, the 3D scaffolds reached the offset yield strength and maintain a steady stress represented by the plateau in Figure 3. Further increase in the strain led to the crushing of the 3D scaffold which resulted in a densification process in the $3 \mathrm{D}$ scaffold. This phenomenon caused the stress level to rise quickly resulting in a steeply rising stress profile.

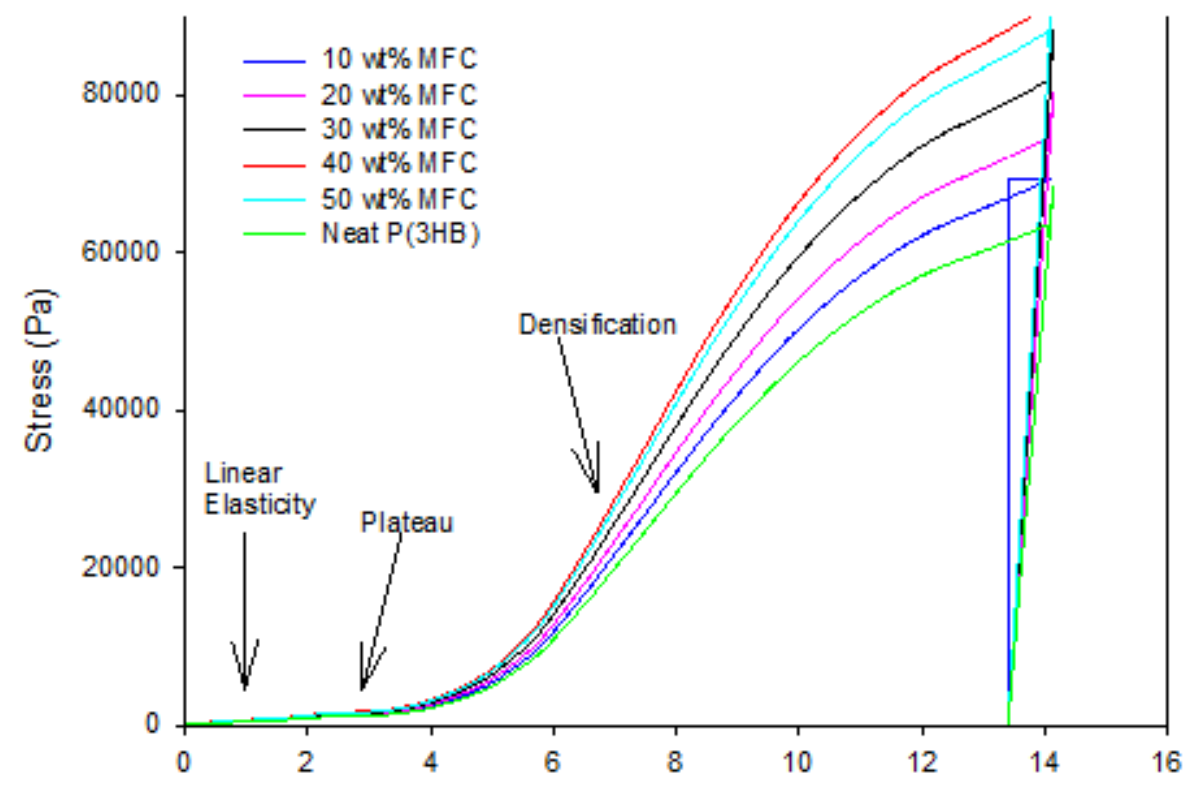

Static Strain (\%)

(A)

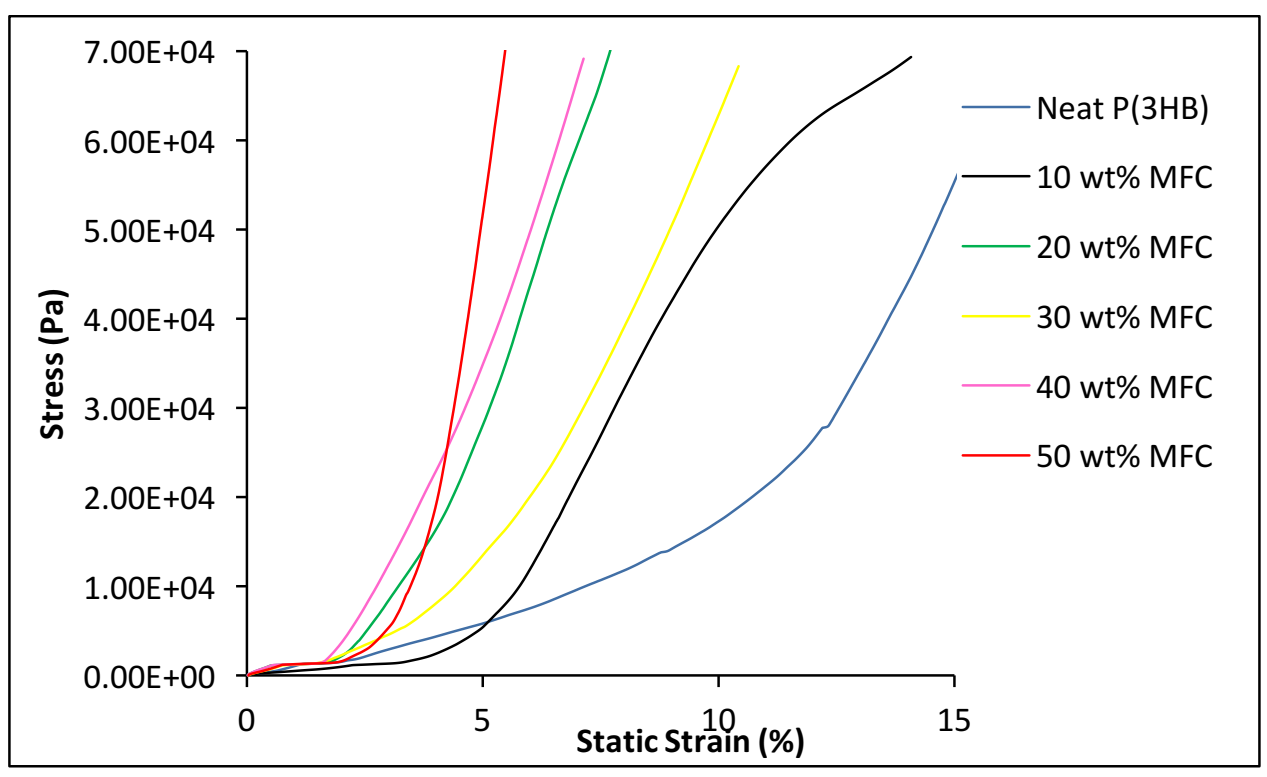


Figure 3. Typical stress-strain curves of neat $\mathrm{P}(3 \mathrm{HB})$ and $\mathrm{P}(3 \mathrm{HB}) / \mathrm{MFC}$ scaffolds of various MFC content under compression loading. (A) Normal curve (B) Enlarged curve for lower strain values. The experiment was performed in triplicates. For the purpose of clarity, only the profiles for single analysis have been shown.

Fig. 4 shows the compressive modulus and compressive yield strength of the neat $\mathrm{P}(3 \mathrm{HB})$ and $\mathrm{P}(3 \mathrm{HB}) / \mathrm{MFC}$ composite scaffold with varying wt $\%$ of MFC content. It can be deduced from Figure 4 that the incorporation of MFC into the polymer matrix significantly influenced the compressive modulus of the composites. Whilst, the compressive modulus of the neat $\mathrm{P}(3 \mathrm{HB})$ was found to be $0.08 \pm 0.01 \mathrm{MPa}$, the compressive modulus on addition of $10,20,30$, and 40 wt $\%$ MFC were found to have increased by 35, 37, 64 and $124 \%$ respectively. From the statistical analysis performed on the result, statistical difference $(p<0.05)$ was found between the compression modulus of the neat $\mathrm{P}(3 \mathrm{HB})$ and the $\mathrm{P}(3 \mathrm{HB}) / \mathrm{MFC}$ composites, and among the composites. However, compressive modulus of the $\mathrm{P}(3 \mathrm{HB}) / \mathrm{MFC}$ composite was found to decrease to $0.16 \pm 0.02 \mathrm{MPa}$ on increasing the MFC content further to $50 \mathrm{wt} \%$. On the other hand, the compressive yield strength of the composite was found to increase progressively with the incorporation of MFC to the polymer matrix. Whilst, the compressive yield strength measured on the neat $\mathrm{P}(3 \mathrm{HB})$ scaffold was $0.58 \pm 0.06 \mathrm{KPa}$, this was found to have improved to $95,97,98,102$ and $109 \%$ with respect to the neat $\mathrm{P}(3 \mathrm{HB})$ scaffold, on addition of 10,20 , 30, 40 and $50 \mathrm{wt} \%$ MFC respectively. Besides, a statistical difference $(p<0.05)$ was calculated between the compressive yield strength of the neat $\mathrm{P}(3 \mathrm{HB})$ scaffold and the $\mathrm{P}(3 \mathrm{HB}) / \mathrm{MFC}$ composite scaffolds. However, no significant difference $(p>0.05)$ was found in the yield strength among the composites containing different amounts of MFC. 


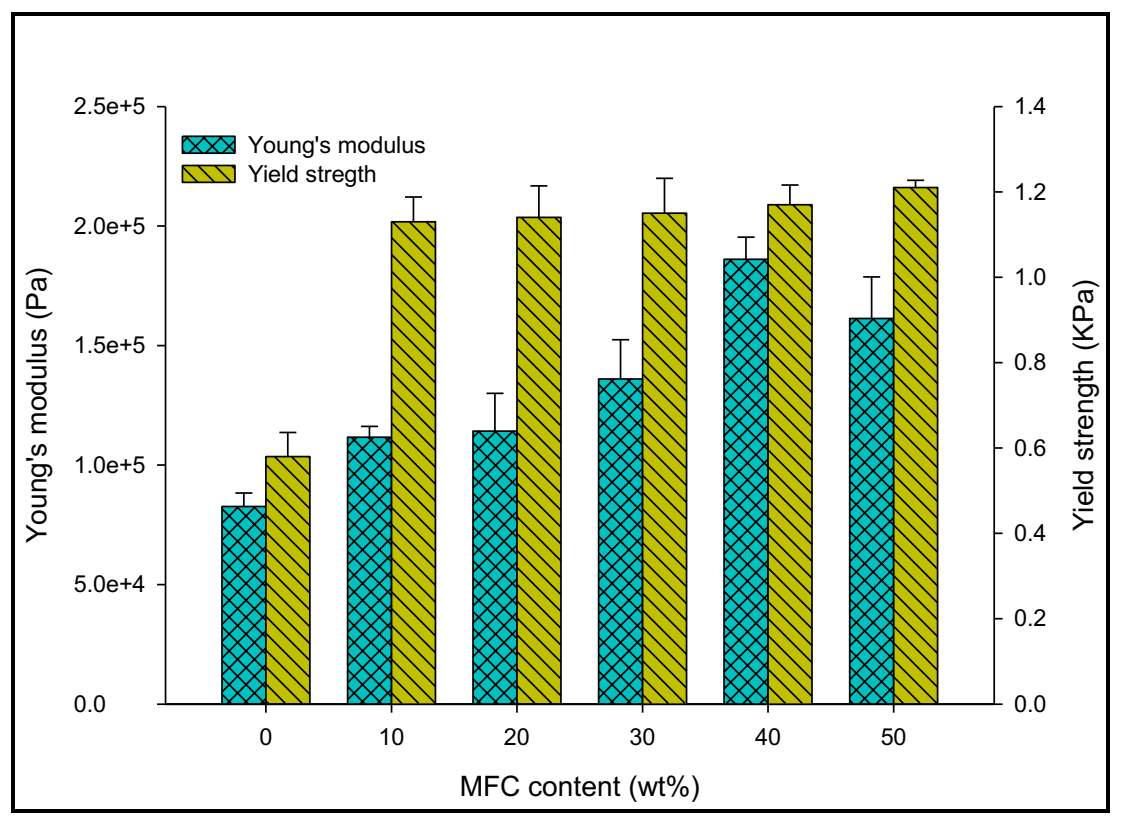

Figure 4. Compressive modulus and yield strength for $\mathrm{P}(3 \mathrm{HB}) / \mathrm{MFC}$ scaffolds with various $\mathrm{MFC}(\mathrm{wt} \%)$ content measured in air $(\mathrm{n}=4$, error $= \pm \mathrm{SD})$.

\subsection{Protein adsorption assay on $P(3 H B) / M F C$ composite $3 D$ scaffold}

Protein adsoprtion was measured on both the neat $\mathrm{P}(3 \mathrm{HB})$ and $\mathrm{P}(3 \mathrm{HB}) / \mathrm{MFC} 3 \mathrm{D}$ scaffold to understand the effect of addition of MFC to the $\mathrm{P}(3 \mathrm{HB})$ matrix on this parameter. This was necessary in order to gain more understanding of the role of the added MFC in protein adsorption by the composite scaffolds. The potential of a biomaterial to function as a scaffold in tissue regeneration is partly based on their role in enhancing cell attachment, differentiation and subsequent tissue formation, which in turn is governed by their capacity for protein adsoprtion. The result of the protein adsorption test shown in Figure 5 showed that the addition of MFC to the polymer matrix improved protein adsoprtion by the composite material by 8 , $15,20,22,27 \%$ by the addition of $10,20,30,40$ and $50 \mathrm{wt} \%$ MFC repectively when compared to $490 \mu \mathrm{g} / \mathrm{cm}^{2}$ protein absorped by the neat $\mathrm{P}(3 \mathrm{HB})$ scaffold. Hence, the protein adsorbed by the composite material increased progressively as the amount of MFC added to the polymer matrix increased. 


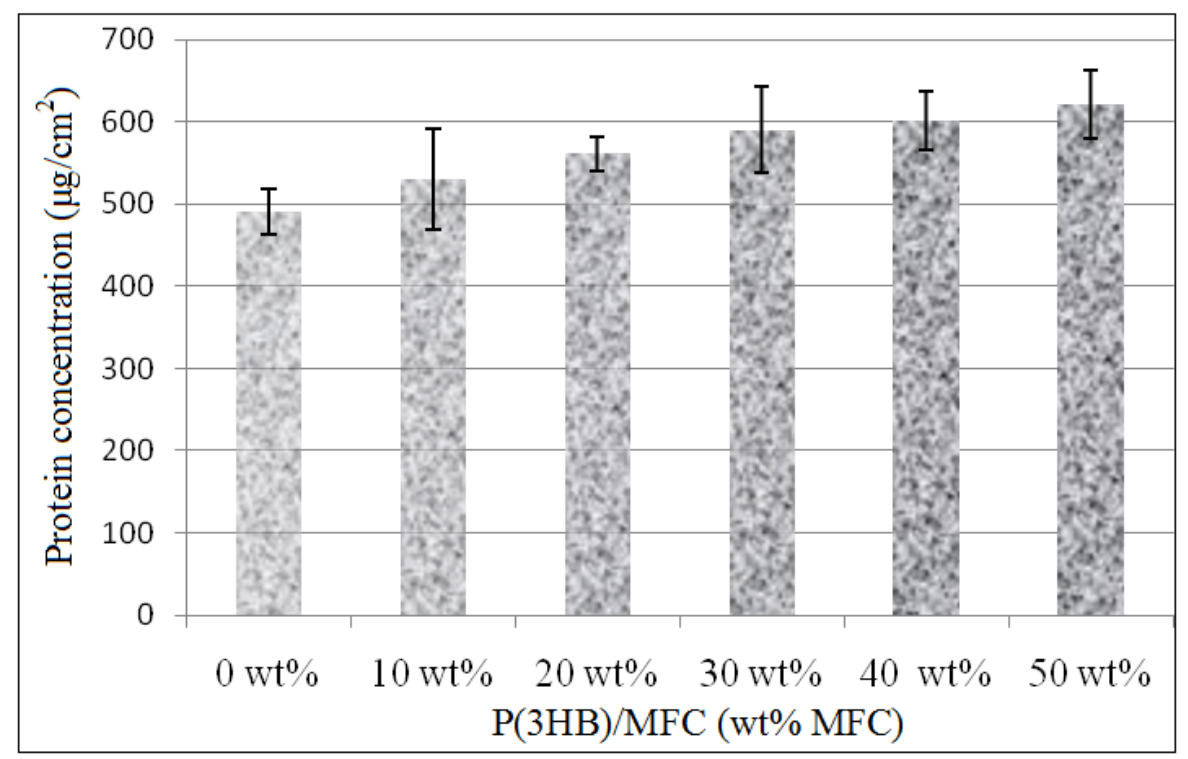

Figure 5: Total protein adsorption study on $\mathrm{P}(3 \mathrm{HB}) / \mathrm{MFC}$ composite scaffold using foetal bovine serum $(n=3$; error bars $= \pm S D)$.

3.5 Change in $\mathrm{pH}$ of the immersed SBF of the neat $P(3 H B)$ and $P(3 H B) / M F C 3 D$ composite scaffolds: It has been suggested that acidic degradation products of polymers such as PLA (polylactic acid) and $\mathrm{P}(3 \mathrm{HB})$ result in a decrease in $\mathrm{pH}$ around the surrounding environment of degrading polymeric materials. ${ }^{55}$ However, the degradation product of $\mathrm{P}(3 \mathrm{HB})$ is much less acidic than that of PLA. Whilst, very low $\mathrm{pH}$ is not desirable during degradation of medical polymeric materials, very high $\mathrm{pH}$ is equally not desirable as this could affect the physiological functions of the surrounding cells and tissues. Hence, the change in the $\mathrm{pH}$ of the immersed SBF for the neat and composite $\mathrm{P}(3 \mathrm{HB})$ materials was monitored over a period of time. The details of the variation in the $\mathrm{pH}$ of the SBF medium are shown in Fig. 6. No rapid change in $\mathrm{pH}$ of the $\mathrm{SBF}$ in the presence of neat $\mathrm{P}(3 \mathrm{HB})$ and the $\mathrm{P}(3 \mathrm{HB}) / \mathrm{MFC}$ composite was observed throughout the incubation period. However, it was found that the $\mathrm{pH}$ of the SBF for the composite samples increased slightly from the initial 7.35 to 7.47 after 7 days of immersion in $\mathrm{SBF}$. The $\mathrm{pH}$ was found to remain constant until after 14 days and later gradually decreased to 6.4 after 30 days of incubation. For the neat $\mathrm{P}(3 \mathrm{HB})$, the $\mathrm{pH}$ was found to increase slightly from the initial 7.35 to 7.45 at 12 days and gradually decrease to a $\mathrm{pH}$ of 5.8. Comparison of decrease in $\mathrm{pH}$ revealed that the $\mathrm{pH}$ decrease in the $\mathrm{SBP}$ with neat $\mathrm{P}(3 \mathrm{HB})$ decreased a lot more than that observed in the composite. Hence, the composite maintained a near neutral $\mathrm{pH}$ which is an advantage for its use as a tissue engineering material. 


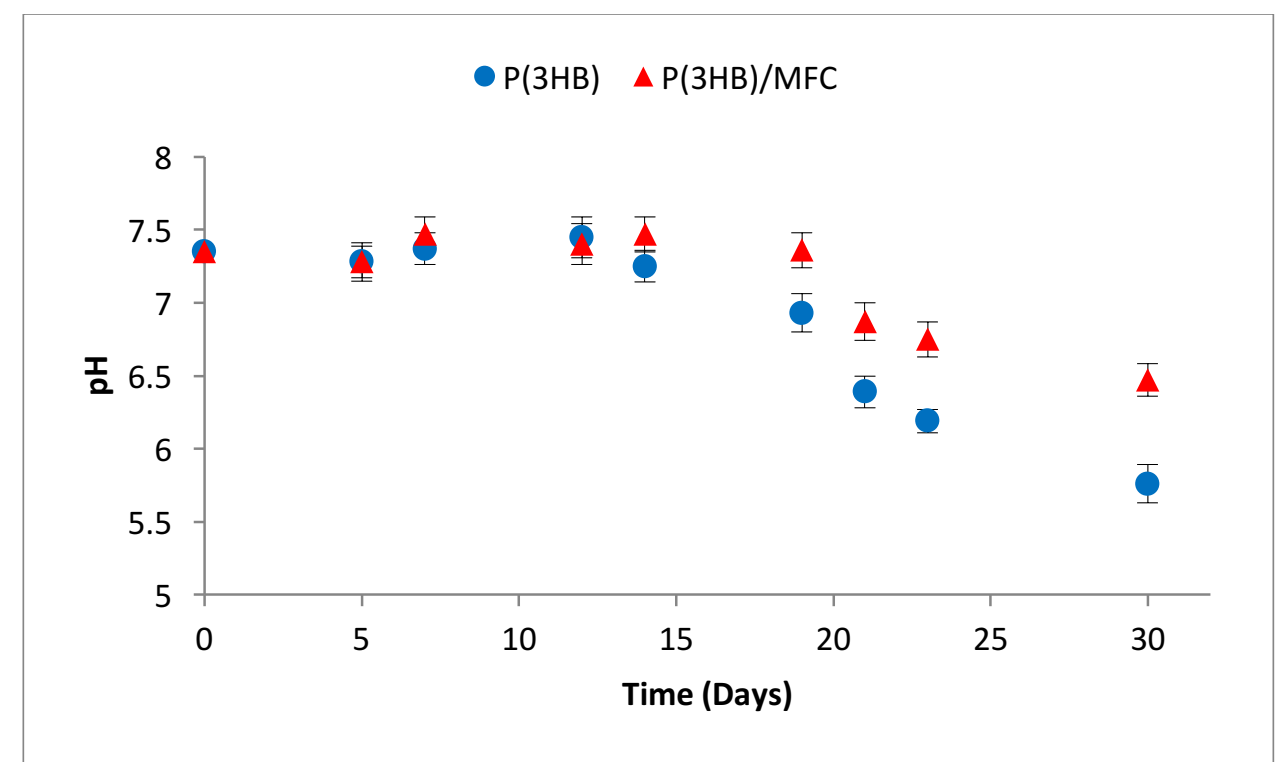

Figure 6. Change in $\mathrm{pH}$ of the $\mathrm{SBF}$ solution in which the neat $\mathrm{P}(3 \mathrm{HB})(\bullet)$ and $\mathrm{P}(3 \mathrm{HB}) / \mathrm{MFC}$ ( $\Delta$ ) 3D scaffold were incubated.

\subsection{Cell Proliferation analysis on $P(3 H B) / M F C$ composite material}

The Murine ATDC5 cell line has been well characterised and validated. It is widely used as an in vitro model of chondrogenesis. ${ }^{82}$ Based on this fact, the cell line was chosen to gain more understanding on the biocompatibility of the $\mathrm{P}(3 \mathrm{HB}) / \mathrm{MFC}$ composite in the context of this cartilaginous cell line. Cell proliferation study of ATDC5 cell lines was measured using the Alamar blue assay. Fig. 7 shows the trend of growth pattern of the ATDC5 cell lines on the neat $\mathrm{P}(3 \mathrm{HB})$ composite scaffold. No significant differences $(p>0.05)$ were found between cell proliferations on the samples analysed at day 1 . However, on day 4 and 7 , slight differences in cell proliferation were noticed on the tested samples. $\mathrm{P}(3 \mathrm{HB}) / \mathrm{MFC} 3 \mathrm{D}$ composite scaffold with $40 \mathrm{wt} \%$ MFC content showed a slightly lower cell proliferation at day 4 (97\%) when compared to the neat $\mathrm{P}(3 \mathrm{HB})$ scaffold samples $(108 \%)$ but on day 7 , it was found that the cell proliferation on the $40 \mathrm{wt} \%$ MFC content composite was higher (117\%) than that observed on the neat $\mathrm{P}(3 \mathrm{HB})$ scaffold (105\%) 


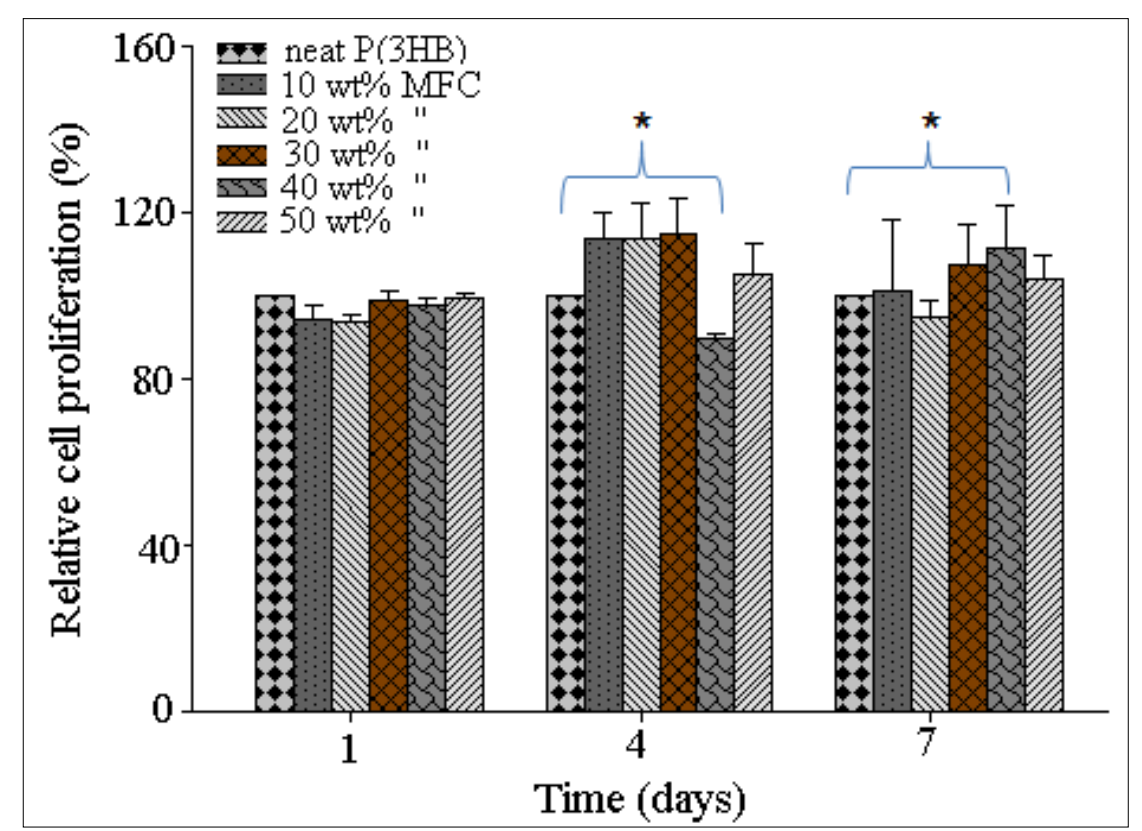

Figure 7: Cell proliferation relative to the control (neat $\mathrm{P}(3 \mathrm{HB})$ ) set at $100 \%$ for 1,4 and 7 days growth, using Alamar Blue assay on $\mathrm{P}(3 \mathrm{HB}) / \mathrm{MFC}$ composite 3D Scaffold with different amount of MFC content. Data $(\mathrm{n}=3$, error bars $= \pm \mathrm{SD}, p<0.01, *)$ were compared using ANNOVA.

\subsection{Cell Morphology}

A detailed morphological study on cell adhesion and proliferation on the $\mathrm{P}(3 \mathrm{HB}) / \mathrm{MFC}$ 3D composite scaffold was further performed on the composite scaffold containing 40 wt\% MFC. Figure 8.0 shows the morphology of the ATDC5 cells on TCP and 2D $\mathrm{P}(3 \mathrm{HB}) / \mathrm{MFC}$ constructs on Day 1 and 7 , as a control for comparison with the morphology observed on the 3D scaffolds described in this work.
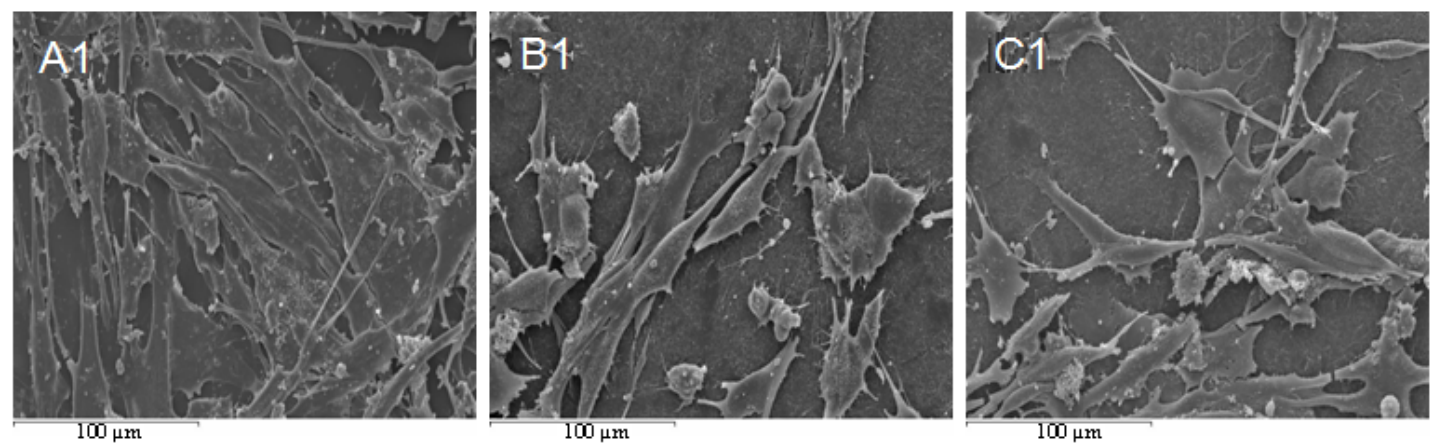

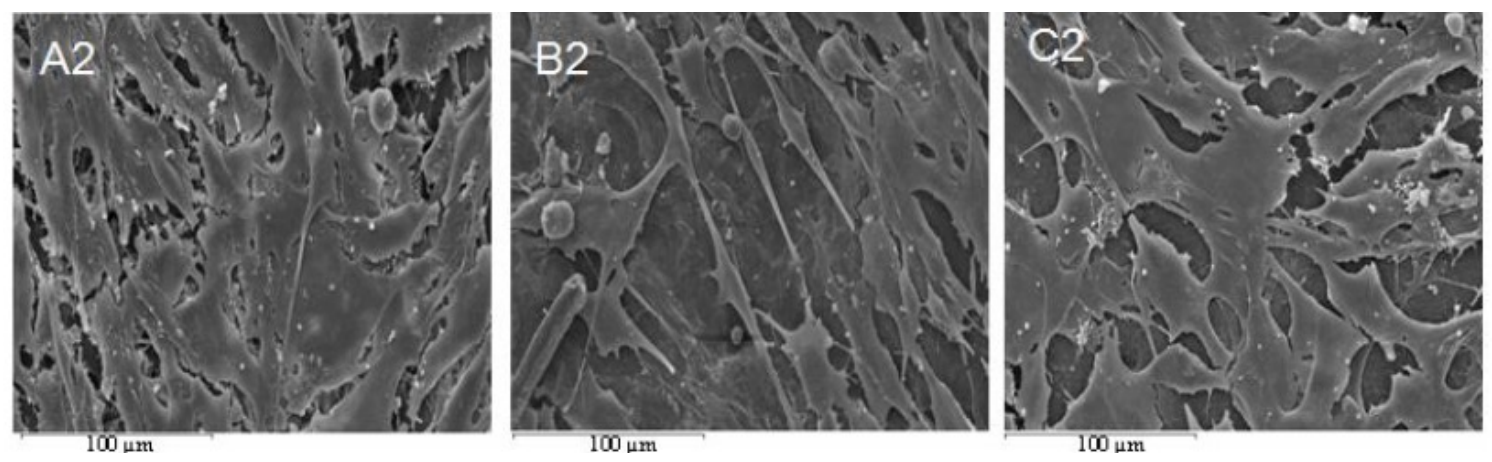

Figure 8.0: SEM images of ATDC cells growing at day 1 on (A1) Tissue culture plastic, (B1) neat 2D P(3HB) film and (C1) neat $\mathrm{P}(3 \mathrm{HB}) / \mathrm{MFC}$ composite films; on day 7 on (A2) Tissue culture plastic, (B2) Neat $\mathrm{P}(3 \mathrm{HB})$ and (C2) $\mathrm{P}(3 \mathrm{HB}) / \mathrm{MFC}$ composite films shown at (x 500) magnifications.

The morphology of the ATDC5 cells grown on the $\mathrm{P}(3 \mathrm{HB}) / \mathrm{MFC}$ composite scaffold on Day 1, 4 and 7 were examined by SEM and typical images are shown in Figs. 8.1, 8.2 and 8.3. No difference was seen in morphology of cells examined with SEM in both the neat $\mathrm{P}(3 \mathrm{HB})$ and composite containing $40 \mathrm{wt} \% \mathrm{MFC}$. However, slightly fewer cells were found in the pores of the neat $\mathrm{P}(3 \mathrm{HB}) 3 \mathrm{D}$ scaffold on day 7 (data not shown). However, cells grown on 40wt\% MFC composite showed long filopodia unlike those grown on the neat $\mathrm{P}(3 \mathrm{HB})$ scaffold. The morphology of the composite scaffold surface proved to provide favourable conditions for the attachment of cells. This is evident from the cell adhesion, cell division, formation of long filopodia and proliferation observed on Day 1 as seen in Fig. 8.1b, c \& e. On Day 4, the cells were found to have a more flattened and stretched morphology, overlaying on each other and occupying and taking up the shape of the pore throat (inside the wall of pore opening) (Fig. 8.2b, e \& f). By day 7 , the cells were found to have grown, bridging the pores in the scaffold and further overlaying on each other (Fig. 8.3). In general, the chondrocytes grew well and exhibited good attachment and morphological features such as long filopodia on the composite scaffolds on Days 1, 4 and 7. 


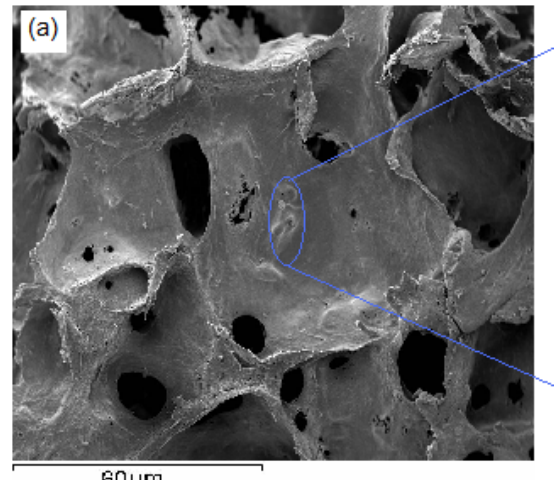

$60 \mu \mathrm{m}$

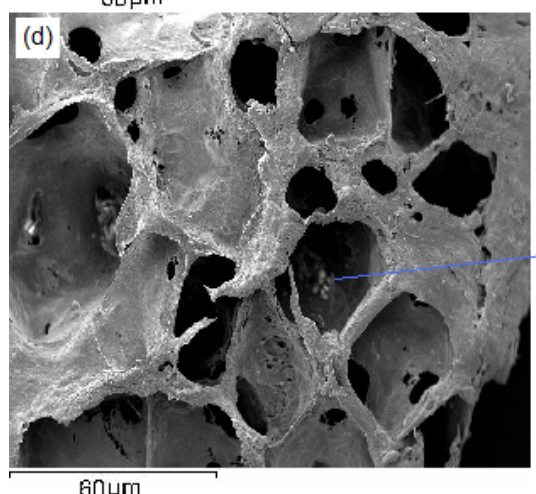

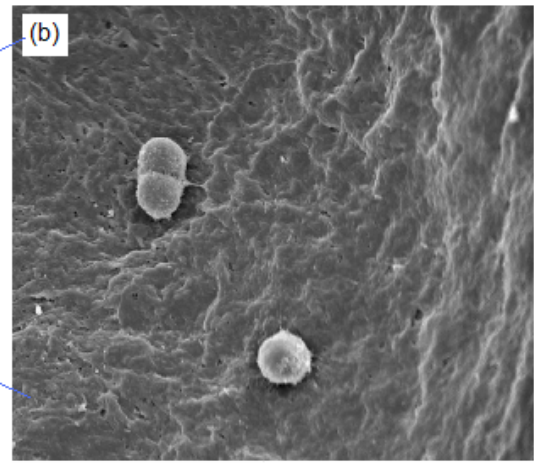

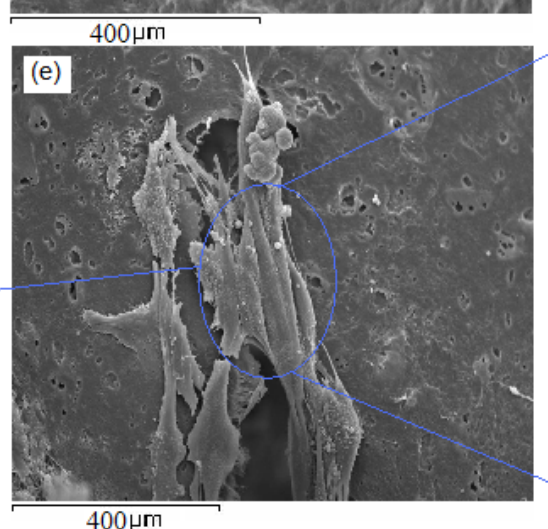

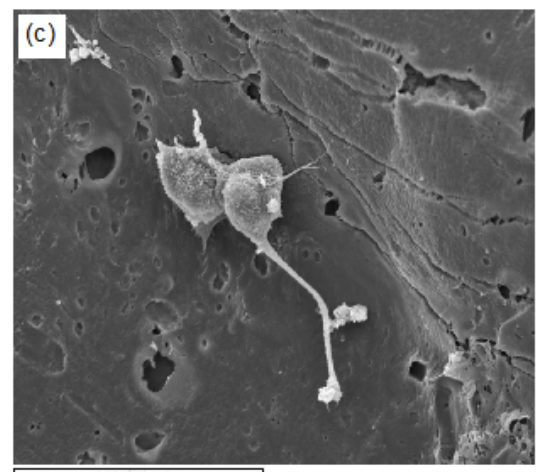

$600 \mu \mathrm{m}$

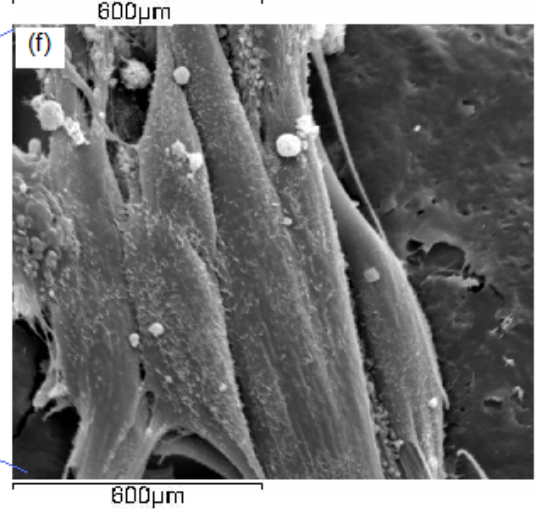

Figure 8.1 SEM micrographs of ATDC5 cells grown on $\mathrm{P}(3 \mathrm{HB}) / \mathrm{MFC}$ composite scaffolds on Day 1; (a) ATDC5 cells growing on the pores in the scaffold; (b) ATDC5 cells still in round shape adhering to the microtopography of the walls of the pores in the scaffold; (c) Cells growing filopodia after division and moving away for flattening; (d) Group of cells growing in the pore of the scaffold material (e) and (f) show a higher magnification of (d) (indicated by the blue line for a clearer view). 

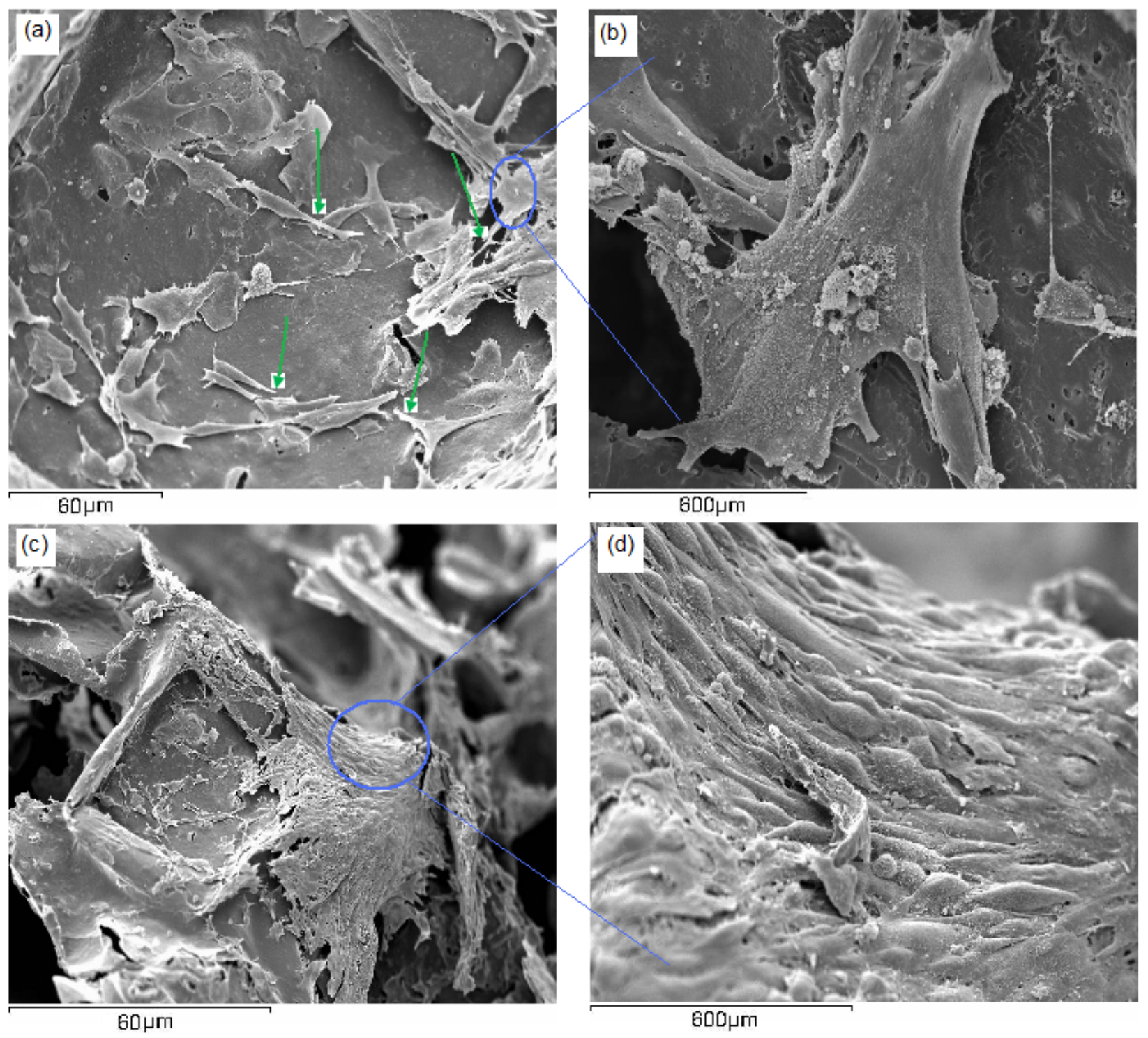

Figure 8.2: SEM micrographs of ATDC5 cells growing within the pores in the $\mathrm{P}(3 \mathrm{HB}) / \mathrm{MFC}$ 3D composite scaffold at Day 4. (a) well spread ATDC5 cells extending their filopodia (b) A higher magnification of (a) Flattening and layering of ATDC5 cells on the polymeric composite 3D substrate; (c) highlights the densely growing ATDC5 cells inside the pore (d) A higher magnification of (c) (indicated by the blue line) The cells began rounding up for division and proliferation. 

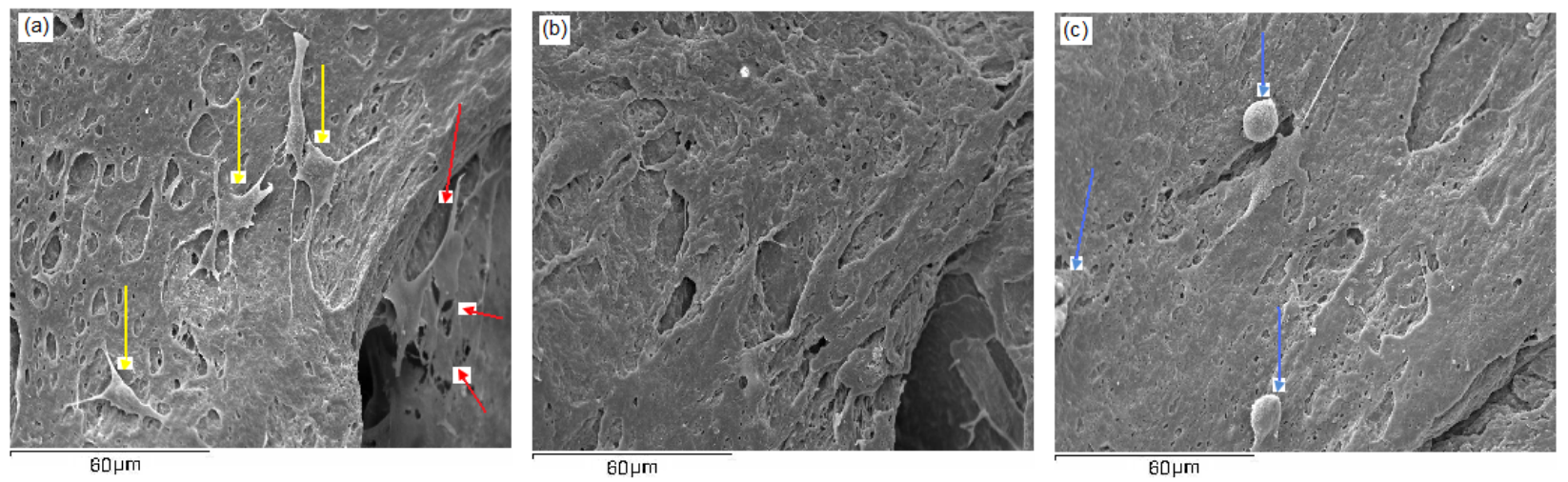

Figure 8.3: SEM micrographs of ATDC5 cells growing in the $\mathrm{P}(3 \mathrm{HB}) / \mathrm{MFC} 3 \mathrm{D}$ composite scaffold at Day 7. The yellow arrows in (a) indicate the folding and withdrawal of filopodia, possibly for division and the red arrow highlights cells growing and bridging the pores. (b) Well flattened cells on the polymeric 3D composite substrate, while the blue arrows in Figure (c) highlight rounded ATDC5 cells ready for division.

Whole Protein Production by Murine ATDC5 cell line grown on 3D P(3HB)/MFC composite: To further understand the capability of the composite material to support the growth of Murine ATDC5 cell line, in order to assess future cartilage formation, whole protein production was investigated. The hypothesis behind this investigation was that since cell activities including cartilage formation, can be correlated with the extracellular whole protein production, increase or decrease in the whole protein released into the surrounding medium is an indication of the ability of the test material to hinder or promote cartilage formation. Statistical analysis performed shows no significant difference $(p>0.01)$ among the test materials (neat $\mathrm{P}(3 \mathrm{HB})$ and $\mathrm{P}(3 \mathrm{HB}) / \mathrm{MFC})$ at various time points investigated.

\section{Discussion}

The use of biomaterial implantation to surpass the limitations of conventional treatments is one of the main objectives of tissue engineering. Tissue engineering has the potential to produce a supply of immunologically tolerant tissue substitutes that can grow with a patient and lead to a permanent solution to a damaged organ or tissue without the need for supplementary therapies. Hence, to repair damaged organ or tissue, relevant cell(s) are required to be grown in vitro into a structure mimicking the three-dimensional structure of the damaged organ or tissue. But, cells lack the ability to grow in favoured 3D orientations and thus define the anatomical shape of the tissue. Instead, they randomly migrate to form a two-dimensional layer 
of cells. Thus, porous 3D scaffolds are required for cell(s) seeding and subsequent cell attachment and colonisation. ${ }^{83}$ Architectural design of tissue engineering scaffolds into porous structures, thus, plays a very important role in permitting cell adhesion, proliferation and characterisation and finally, defines the ultimate shape of the new tissue.

Both the neat $\mathrm{P}(3 \mathrm{HB})$ and composite porous scaffolds produced using the novel compression moulding/particulate leaching were in general very homogenous, since the formation of agglomerates was not observed. The absence of agglomeration confirmed that the acetylation of the easily accessible surface hydroxyl groups $(\mathrm{OH})$ made the MFC more compatible with the non polar solvent used and the $\mathrm{P}(3 \mathrm{HB})$ matrices. This ensured the formation of a well dispersed homogenous mixture of $\mathrm{P}(3 \mathrm{HB})$ and $\mathrm{MFC}$ for composite production. The more important aspect of the novel technique used in the production of the scaffolds is that the technique is very simple, inexpensive and less time consuming unlike solvent casting/particulate leaching or electrospinning. Furthermore, the porous microstructure produced using this technique is comparable and in many cases better in the physicomechanical properties (compressive modulus of 0.19 MPa and yield strength of approximately $1.20 \mathrm{KPa}$ with the addition of $40 \mathrm{wt} \%$ of MFC) than the ones achieved for other PHA scaffolds reported so far in literature like $\mathrm{P}(3 \mathrm{HB}-\mathrm{co}-3 \mathrm{HV}) / \mathrm{BG}$ scaffold prepared using compression moulding, thermal processing, and salt particulate leaching technique. ${ }^{84}$

The SEM micrographs provide evidence of the strong interfacial adhesion between the cellulose fibres and the $\mathrm{P}(3 \mathrm{HB})$ matrix, as shown by excellent cellulose fibre dispersion within the $\mathrm{P}(3 \mathrm{HB})$ matrix, without noticeable aggregates. It was indeed observed that the characteristic nano- and micro-fibril network of MFC was maintained and totally impregnated within $\mathrm{P}(3 \mathrm{HB})$ matrix. These results clearly corroborated the superior mechanical properties of the MFC-based composites compared with those of the neat $\mathrm{P}(3 \mathrm{HB})$ counterparts, as suggested by the mechanical tests discussed below. Surface topography is very important for the adhesion of mammalian cells on biomaterials and this was observed on the throats of the pores in the scaffold. The surface microtopography can be attributed mainly to the homogenous dispersion of the MFC filler. The surface structures of the sucrose grains which formed the pores would have also contributed to the microtopography. The interconnected pore network in the scaffold was as a result of the amount of sucrose grains added and the homogenous mixture of the composite and the sucrose grains during scaffold fabrication.

Generally, incorporation of additives into a polymer matrix is an effective way of improving the physico-mechanical properties of biomaterial for specific tissue engineering applications. 
Large increments in the mechanical performance of several composite materials have previously been reported by the incorporation of modest proportions of bacterial cellulose nano-fibres in other kinds of matrices. ${ }^{85}$ Li et al., observed the improvement of the compressive yield of $\mathrm{P}(3 \mathrm{HB}-\mathrm{co}-3 \mathrm{HV})$ by $156 \%$ of the initial strength of the polymer on addition of $20 \mathrm{wt} \%$ of Bioglass ${ }^{\circledR} .86$ Hence, the superior mechanical properties of $\mathrm{MFC} / \mathrm{P}(3 \mathrm{HB})$ composites compared with the neat $\mathrm{P}(3 \mathrm{HB})$ scaffold, confirmed the good interfacial adhesion and the strong interactions between the MFC and the $\mathrm{P}(3 \mathrm{HB})$ matrix. These results can be explained by the inherent morphology of bacterial cellulose with its nano- and micro-fibrillar network. The reinforcing effect might result from the effect of formation of a stiff hydrogen bonded cellulose network. ${ }^{87}$ This behaviour was attributed to an improved dispersion and / or compatibility between the bulk $\mathrm{P}(3 \mathrm{HB})$ and the modified MFC. Thus, increasing the amount of MFC in the $\mathrm{P}(3 \mathrm{HB})$ matrix increased the compressive modulus and compressive yield strength of the composites. The increased compressive modulus is an excellent property that will allow the use of this composite in load bearing applications where the neat polymer will fail due to poor mechanical properties. Surprisingly, the composite with $50 \mathrm{wt} \%$ MFC did not show the highest compressive modulus, indicating that there is a limit to the amount of MFC that can be added to the polymer matrix to improve the compressive yield strength.

Investigations on the total protein production showed none of the tested material hindered total protein production. However, Hardingham et al. have observed that chondrocytes grown on bacteria cellulose monolayer became fibroblastic and lose their characteristic pattern of matrix protein production. ${ }^{88}$ In this work, the $\mathrm{P}(3 \mathrm{HB}) / \mathrm{MFC}$ composite material was able to support growth of chondrocytes and did not induce the cells to differentiate into fibroblasts. This is due to the nano- and micro-structural surfaces provided by a combination of both MFC fibres and $\mathrm{P}(3 \mathrm{HB})$ matrix which fundamentally enhanced protein-surface interactions, thus, making the composite material, a good material for cartilage tissue engineering.

Gopferich has observed that $\mathrm{pH}$ is an important factor that influences the rate of hydrolysis during degradation in polymers. ${ }^{89}$ The $\mathrm{pH}$ of SBF in which both types of samples were immersed increased a little above the initial $\mathrm{pH}$ of the buffer (7.35). Since the degradation product of $\mathrm{P}(3 \mathrm{HB})$ is a 3-hydroxy butyric acid and the pKa of 3-hydroxybutyric acid is 4.70 , so at $\mathrm{pH} 7.35$, the 3-hydroxybutyric acid will be in the anionic form, i.e. the basic form, leading to a rise in $\mathrm{pH}$ of the SBF. However, once the concentration of 3-hydroxybutyric acid reaches beyond a critical concentration due to the degradation of the polymer, the SBF is no longer 
able to maintain the $\mathrm{pH}$ at 7.35 and the $\mathrm{pH}$ falls slightly due to the acidic nature of 3-hydroxybutyric acid.

The cellular morphology and proliferation on biomaterials may be affected by the presence of non-structural patterns and surface-protein interactions. Several studies previously analysed the proliferation of different cell lines on both $\mathrm{P}(3 \mathrm{HB})$ and bacterial cellulose membranes, confirming their non-toxicity and applicability as scaffolds for cell proliferation. However, depending on the cell lines used, the effect of the biomaterial on the proliferation rate and the cell morphology may be quite different. ${ }^{90}$ Several studies showed that the cytotoxicity of a biomaterial is many times cell-specific. ${ }^{91}$ The results of the cell proliferation assay performed on the 3D composite materials corresponded with the observations on SEM images of the Murine ATDC5 cells grown on both scaffold materials. The cell proliferation results achieved with the neat $\mathrm{P}(3 \mathrm{HB})$ and $\mathrm{P}(3 \mathrm{HB}) / \mathrm{MFC}$ composite containing $40 \mathrm{wt} \% \mathrm{MFC}$, did not differ much on Day 1. This can be attributed to the microstructure, the 3D topography, surface-protein interactions and the presence of 3D pores where cells infiltrated, thereby resulting in good cell growth. Chondrocytes obtain a more extended morphology when grown on a two-dimensional surface, while a three-dimensional structure supports chondrocyte proliferation and differentiation. ${ }^{92}$ Thus; the 3D structure and surface-protein interactions were the dominant factors in enhancing cell adhesion and proliferation. When a solid surface is placed in a solution containing a given protein, the protein will generally tend to rapidly adsorb until it saturates the surface. If the surface is hydrophobic, like in the case of the neat $\mathrm{P}(3 \mathrm{HB})$ scaffold, the protein will tend to adsorb by the various hydrophobic patches of residues present on the protein's amphiphilic surface, with the protein then tending to unfold and spread its hydrophobic core over the surface owing to the thermodynamic driving force to reduce the net hydrophobic surface area of the system exposed to the solvent. Hydrophilic surface, on the other hand, tend to interact with the charged and polar functional groups of the protein's surface, thus influencing adsorbed protein orientation, but with a lower tendency to cause the protein to unfold and spread over the surface. Because proteins generally do not tend to adsorb non-specifically to themselves, protein adsorption tends to stop once complete monolayer coverage is achieved. The final organisation of the adsorbed protein layer (i,e, the organisation, conformation, and packing arrangement of the adsorbed proteins) depends on the chemical and physical structure of the protein, the surface, and the aqueous solution, and the thermodynamics of the interactions between these system components. It is also strongly influenced by the kinetics of mass transport of the protein to the surface from solution relative to the kinetics of 
the protein's movement on the surface, the kinetics of protein spreading on the surface and the physical constraints imposed by protein-protein interactions on the surface ${ }^{93}$. Hence, the composite scaffolds can be said to have amphiphilic properties and were expected to have more organised, conformed, and packing arrangement of the adsorbed proteins than the neat $\mathrm{P}(3 \mathrm{HB})$ scaffold and this will encourage increased proliferation as observed in this work. Hence, the amount and type of serum protein that adhered to the substrates vary on different chemical surfaces; this can also affect cell behaviour on the substrates ${ }^{94}$.

\section{Conclusion}

Scaffolds provide a 3D environment that is desirable for the production of cartilaginous tissue. Current work on alternatives to single phase 3D scaffolds is expanding, and the potential of MFC and $\mathrm{P}(3 \mathrm{HB})$ composites have been explored in this work. The much improved load bearing properties of the composite scaffolds in combination with the biocompatibility achieved provided evidence of the future potential of these natural polymer-based 3D $\mathrm{P}(3 \mathrm{HB}) / \mathrm{MFC}$ composite scaffolds in load bearing joint cartilages. The results obtained highlighted the positive effects of the MFC on the effective microtopography within the composite. In addition, the three-dimensional composite produced in this work were characterised by high porosity, with a regular distribution of pore diameter, high-surface area to volume ratio, and morphological similarities to extracellular matrix. These physical characteristics promote favourable biological responses of seeded cells in vitro, including enhanced cell attachment, proliferation and maintenance of the chondrocytic phenotype. ${ }^{95}$ Further studies using these promising materials will involve detailed in vivo work which will allow the generation of preclinical data for these promising materials. Hence, in conclusion, the results obtained in this work confirm for the first time the huge potential of the $\mathrm{P}(3 \mathrm{HB}) / \mathrm{MFC}$ composites in the development of load bearing polymer-based cartilage repair implants to meet the currently unmet needs in this area.

\section{References}

1. Langer RS and Vacanti JP. Scientific American 280:86-89 (1999).

2. Yannas IV, Lee E, Orgill DP, Skrabut EM and Murphy GF. PNAS 86: 933-937 (1989).

3. Atala A, Bauer SB, Soker S, Yoo JJ and Retik AB. Lancet 367: 1241-1246 (2006). 
4. Macchiarini P, Jungebluth P, Go T, Asnaghi MA, Rees LE, Cogan TA, Dodson A, Martorell J, Bellini S, Parnigotto PP, Dickinson SC, Hollander AP, Mantero S, Conconi MT and Birchall MA. Lancet 372: 2023-230 (2008).

5. Schimming R and Schmelzeisen R. J Oral Maxillofac Surg 62: 724-729 (2004).

6. Warnke PH, Springer IN, Wiltfang J, Acil Y, Eufinger h, Wehmöller m, Russo PA, Bolte H, Sherry E, Behrens E and Terheyden H. Lancet. 364: 766-770 (2004).

7. Vacanti JP. Tissue Eng 13: 231-232 (2007)

8. Chung C and Burdick JA. Adv Drug Deliv Rev 60: 2. 243-262 (2008).

9. Zhang R and Ma PX. Biome. Mater Res 52: 430 (2000)

10. Hutmacher DW, Schantz JT, Zein I, Ng KW, Teoh SH and Tan KC. J Biomed Mat Res 55:2. 203-216 (2001).

11. O’Brien FJ. Materials today 14: 3. 88-95 (2011).

12. Lange R, Luthen F, Beck U, Rychly, Baumann JA and Nebe B. Biomol Eng 19:2-6. 255$261(2002)$.

13. He W, Gonsalves KE, Batina N, Poker DB, Alexander E and Hudson M. Biomed Dev 5:2. 101-108 (2003).

14. Cassinelli C, Morra M, Bruzzone G, Carpi A, Di Santi G, Giardino R and Fini M. Int J Oral \& Maxillofac. Impl 18:1. 46-50 (2003).

15. Langer R and Vacanti JP 260:5110, 920-926 (1993).

16. Hutmacher DW. Biomat 21:24 2529-2543 (2000).

17. Agrawal CM and Ray RB. J Biomed Mat Res 55:2. 141-150 (2001).

18. Leong KF, Cheah CM and Chua CK. Biomat 24:13 3262-2378 (2003).

19. Yang S, Leong KF, Du Z and Chua CK. Tissue Eng 7:6. 679-689 (2001).

20. Ko HC, Milthorpe BK and McFarland CD. Eur Cell Mater 14: 1-18 (2007)

21. Wu W, Feng X, Mao T, Feng X, Ouyang HW, Zhao G and Chen F. Br J Oral Maxillofac Surg 45: 272-278 (2007).

22. Mikos AG, Thorsen AJ, Czerwonka LA, Bao Y, Langer R, Winslow DN and Vacanti JP. Polymer 35:5. 1068-1077 (1994).

23. Yoon JJ and Park TG. J Biomed Mat Res 55:3. 401-408 (2001).

24. Agrawal CM, Mckinney JS, Huang D and Athanasiou KA. 1st Ed Philadelfia 2000.

25. Murphy WL, Dennis RG, Kileney JL and Mooney DJ. Tissue Eng 8:1. 43-52 (2002).

26. Holly CE, Schoichet MS and Davies JE. J Biomed Mat Res 51:3 376-382 (2000).

27. Karp JM, Shoichet MS and Davies JE. J Biomed Mat Res 64A:2. 388-396 (2003). 
28. Mikos AG, Bao Y, Cima LG, Ingber DE, Vacanti JP and Langer RJ. Biomed Mat Res 27:2. 183-189 (1993).

29. Kim BS and Mooney DJ. J Biomed Mat Res 41:2. 322-332 (1998).

30. Leong KF, Cheah CM and Chua CK. Biomat 24:13 3262-2378 (2003).

31. Gomes ME, Ribeiro AS, Malafaya PB, Reis RL and Cunha AM. Biomat 22:9. 883-889 (2001).

32. Gomes ME, Godinho JS, Tchalamov D, Reis RL and Cunha AM. Mat Sci \& Eng C 20:12, 19-26 (2002).

33. Washburn NR, Simon Jr. CG, Tona A, Elgendy HM, Karim A and Amis EJ. J Biomed Mat Res 60:1, 20-29 (2002).

34. Thomson RC, Yaszemski MJ, Powers JM and Mikos AG. J Biomat Sci polim Ed 7:1. 2338 (1995).

35. Gomes ME, Malafaya PB and Reis RL. Mol Biol Ser The Humana Press Inc, Totowa 2003.

36. Mooney DJ, Baldwin DF, Suh NP, Vacanti JP and Langer R. Biomat 17:14. 1417-1422 (1996).

37. Shea LD, Wang D, Franceschi RT and Mooney DJ. Tissue Eng 6:6. 605-617 (2000).

38. Malafaya PB and Reis RL. Trans Tech Pub, Zurich 39: 240-242 (2003).

39. Mao JS, Zhao LG, Yin YI andYao KD. Biomat 24:6. 1067-1074 (2003).

40. Li WJ, Danielson KG, Alexander PG and Tuan RS. J Biomed Mat Res Part A 67A:1105$1114(2003)$.

41. Hutmacher DW. J Biomater Sci Polym Ed 12: 107-124 (2001).

42. Shen F, Cui YL, Yang LF, Yao KD, Dong XH, Jia WY and Shia HD. Polym Int. 49:12. 1596-1599 (2000).

43. Cima LG, Vacanti JP, Vacanti C, Ingber D, Mooney D and Langer R.. J Biomechan Eng 113:2. 143-151 (1991).

44. Park A, Wu B and Griffith LG. J Biomat Sci Polym Ed. 9:2, 89-110 (1998).

45. Lam CXF, Mo XM, Teoh SH and Hutmacher DW. Mat Sci \& Eng C 20:1-2. 49-56 (2002).

46. Sherwood JK, Riley SL, Palazzolo R, Brown SC, Monkhouse DC, Coates M, Griffith LG, Landeen LK and Ratcliffe A. Biomat 23:24. 4739-4751 (2002).

47. Landers R and Mulhaupt R. Macrom Mat Sci \& Eng 282:1.17-21 (2000).

48. Landers R, Pfister A, Hubner U, John H, Schmelzeisen R and Mulhaupt R. J Mat Sci Mat Med. 37:15. 3107-3116 (2002).

49. Yoshikawa H, Myoui A. J Artif Organs 8: 131-136 (2005). 
50. Ambrosio AM, Sahota JS, Khan Y and Laurencin CT. J Biomed Mater Res 58: 295-301 (2001).

51. Adams CS, Mansfield K, Perlot RL and Shapiro IM. J Biol Chem 276:23. 20316-20322 (2001).

52. Lu 1, Peter SJ, Lyman MD, Lai H-L, Leite SM, Tamada JA, et al. Biomat 21: 1837-1845 (2000).

53. Oh SH, Kang SG, Kim ES, Cho SH and Lee JH. Biomat 24: 4011-4021 (2003).

54. Rowlands AS, Lim SA, Martin D and Cooper-White JJ. Biomat 28: 2109-2121(2007).

55. Liu H, Slamovich EB and Webster TJ. Int J Nanomedicine 1: 541-545 (2006).

56. Kim SS, Park MS, Jeon O, Choi CY and Kim B.S. Biomat 27: 1399-1409 (2006).

57. Huang YX, Ren J, Chen C, Ren TB and Zhou XY. Biomater Appl 22. 409-432 (2008).

58. Damadzadeh B, Jabari H, Skrifvars M, Airola K, Moritz N and Vallittu PK. J Mater Sci Mater Med. 21: 2523-2531 (2010).

59. Friess W and Schlapp M. Eur J Pharm Biopharm. 63: 176-187 (2006).

60. Wu W, Feng X and Mao T. Br J Oral Maxillofac Surg 45: 272-278 (2007).

61. Kim SW, Lee SH, Kang JS and Kang KH. Int J Thermophys 27: 6. 1873-1881 (2006).

62. Helenius G, Bäckdahl H, Bodin A, Nannmark U, Gatenholm P and Risberg B. J Biomed Mater Res: Part A 76A: 2.431-438 (2005).

63. Iguchi M, Yamanaka S and Budhiono A. J Mater Sci 35: 261-270 (2000).

64. Nakagaito AN, Iwamoto S and Yano H. Appl Phys A Mat Sci Process 80: 93-97 (2005).

65. Bae S and Shoda M. Biotechnol Bioeng 90: 20-28 (2005).

66. Bae S, Sugano Y and Shoda M J Biosci Bioeng 97: 33-38 (2004).

67. Czaja W, Krystynowicz A, Bielecki S and Brownjr R. Biomat 27:145-151 (2006).

68. Grande CJ, Torres FG, Gomez CM, Troncoso OP, Canet-Ferrer J and Martinez Pastor J. Polym Polym Composites 16: 181-185 (2008).

69. Li J, Wan Y, Li L, Liang H and Wang J. Mater Sci Eng C 29: 1635-1642 (2009).

70. Grande CJ, Torres FG, Gomez CM and Bañó MC. Acta Biomater 5: 1605-1615 (2009).

71. Chen YM, Xi T, Zheng Y, Guo T, Hou J, Wan Y and Gao C. J Bioact Compat Polym 24:S137-S145 (2009).

72. Mendes PN, Rahal SC, Pereira-Junior OP, Fabris VE, Lenharo SL, de Lima-Neto JF and da Cruz Landim-Alvarenga F. Acta Vet. Scand 51: 12 (2009)

73. Helenius G, Bäckdahl H, Bodin A, Nannmark U, Gatenholm P and Risberg B. J Biomed Mater Res 76: 431-438 (2006). 
74. Shi S, Chen S, Zhang X, Shen W, Li X, Hu W and Wang H. J Chem Technol Biotechnol 84: 285-290 (2009).

75. Gao C, Xiong GY, Luo HL, Ren KJ, Huang Y and Wan YZ. Cellulose 17: 365-373 (2010).

76. Raghunath J, Rollo J, Sales KM, Butler PE and Seifalian AM. Biotechnol Appl Biochem 46: 73-84 (2007).

77. Raghunath J, Salacinski HJ, Sales KM, Butler PE and Seifalian AM. Curr Opin Biotechnol 16: 503-509 (2005).

78. Akaraonye E, Moreno C, Knowles JC, Keshavarz T and Roy I, J. Biotechnol 7:293-303 (2011)

79. Lebourg M, Sabater SR, Mas EJ, Hernandez SF, Gomez RJL and Suay AJ, J. Mater Sci. Mater Med 19:2047-2053 (2008)

80. Jones JR, Poologasundarampillai G, Atwood RC, Bernard D and Lee PD, Biomat 28:1404 (2007)

81. Khanna S and Srivastava AK, Proc Biochem 40:607-619 (2005)

82. Challa TD, Rais Y and Ornan EM, Mol. Cell Endocrinol 323: 282-291(2010)

83. Langer L and Vacanti JP, Science 260: 920 (1993)

84. Li J, Yun H, Gong Y, Zhao N and Zhang X, J Biomed Mater Res A75:985 (2005).

85. Nakagaito AN, Iwamoto S and Yano H, Appl Phys AMater Sci Process 80:93-97 (2005)

86. Li H and Chang J, Biomat 25: 5473 (2004)

87. Siqueira G, Bras J and Dufresne A, Biomacromol 10(2)425-432 (2009)

88. Hardingham T, Tew S and Murdoch A, Arthritis res 4(Suppl 3): 63-8 (2002)

89. Gopferich A, Biomat 17:103-114 (1996)

90. Sanchavanakit N, Sangrungraungroj W, Kaomongkolgit R, Banaprasert T, Pavasant P and Phisalaphong M, Biotechnol Prog 22:1194-1199 (2006)

91. Cullen RT, Moller BG, Jones AD and Davis JMG, Ann. Occup. Hyg 46, 81-84 (2002)

92. Hutmacher DW, Biomat 21:2529-2543 (2000)

93. Latour RA. Encyclopedia of biomaterials and biomedical engineering. New York: Marcel Dekker (2004).

94. Tamada Y and Ikata Y. J Biomed Mater Res 28, 783- 788 (1994).

95. Li WJ, Danielson KG, Alexander PG and Tuan RS, .J.Biomed Mater Res 67A:1105-14 (2003). 